See discussions, stats, and author profiles for this publication at: https://www.researchgate.net/publication/305734955

\title{
Stock price crash risk: Review of the empirical literature
}

Working Paper · August 2016

DOI: 10.13140/RG.2.1.5124.8881

CITATIONS

2

\section{3 authors:}

A Ahsan Habib

Massey University, Albany, Auckland

66 PUBLICATIONS 472 CITATIONS

SEE PROFILE

(2) Mostafa Monzur Hasan

Curtin University

29 PUBLICATIONS 82 CITATIONS

SEE PROFILE
READS

1,260
Haiyan Jiang
The University of Waikato
214 PUBLICATIONS $\quad \mathbf{7 , 0 7 1}$ CITATIONS
SEE PROFILE 


\title{
Stock price crash risk: Review of the empirical literature
}

\author{
Ahsan Habib* \\ School of Accountancy \\ MASSEY UNIVERSITY \\ PRIVATE BAG 102904 \\ AUCKLAND \\ NEW ZEALAND \\ Phone: +64 94140800 \\ FAX: +64 63505618
}

Email: a.habib@massey.ac.nz

\author{
Haiyan Jiang \\ School of Accountancy \\ Massey University \\ Private Bag 102904 \\ Auckland, New Zealand \\ Email: hjiang@massey.ac.nz \\ $\&$ \\ Mostafa Monzur Hasan \\ School of Economics and Finance \\ CURTIN UNIVERSITY \\ PERTH \\ AUSTRALIA
}

Email: monzur.hasan@gmail.com

* Contact author 


\title{
Stock price crash risk: Review of the empirical literature
}

\begin{abstract}
:
We survey the burgeoning literature on the determinants of future stock price crash risk in the US, as well as in countries outside the US. Stock price crash risk, a manifestation of extreme negative values in the distribution of firm-specific returns, has attracted considerable research interests. According to Jin and Myers (2006), when cash flow is lower than investors expect, managers hide the bad news in an effort to protect their jobs. However, when the accumulated bad news finally crosses a tipping point, managers release all the bad news at once, which then results in a stock price crash. We synthesize a vast body of literature on the determinants of crash risk, identify weaknesses, and offer future research opportunities. We categorize the determinants into: (i) financial reporting and corporate disclosures, (ii) managerial incentives and managerial characteristics, (iii) capital market transactions, (iv) corporate governance mechanisms, and (v) informal institutional mechanisms. Despite a large body of research into the determinants of crash risk, very little research attention has been directed towards understanding the consequences of stock price crash.
\end{abstract}

Keywords: Stock price crash risk; financial reporting; corporate governance; non-formal institutions 


\section{Introduction}

We survey the burgeoning literature on the determinants and consequences of future stock price crash risk (hereafter crash risk) in the US, as well as in countries outside the US. We intend to synthesise a rather vast body of literature on this topic, identify weaknesses, and offer future research opportunities. Research on crash risk has received considerable academic interest in recent accounting and finance literature. ${ }^{1}$ According to Jin and Myers (2006), when cash flow is lower than investors expectation, managers have incentives to hide the bad news because of career and short-term compensation concerns. However, when the accumulated bad news finally crosses a tipping point, managers release all the bad news at once, which then results in a stock price crash.

Crash risk, an important feature of return distribution, has important implications for portfolio theories, and for asset and option-pricing models (Kim and Zhang, 2014). Sunder (2010) contends that, unlike risks emanating from systematic volatilities, crash risk cannot be mitigated through portfolio diversification. Harvey and Siddique (2000) also suggest that investors expect higher returns for stocks with more negative skewness, implying that conditional skewness is a priced risk factor. The stock market turmoil in recent years also indicates the significance of crash risk to investors. Thus, understanding what affects investors' perceived crash risk has the potential to make a significant contribution towards protecting shareholder value.

The bulk of the recent empirical research on the determinants of crash risk follows the theoretical framework of Jin and Myers (2006), who argue that the existence of information

${ }^{1}$ Consistent with Chen et al. (2001) we adopt a narrow perspective for defining 'crashes': conditional skewness of the firm-specific return distribution. Hence our review is outside the purview of stock market crash literature (e.g., Schwert, 1990; Amihud, Mendelson, and Wood, 1990). 
asymmetries between corporate insiders and external stakeholders could contribute to crash risk. Asymmetric information allows managers to hide bad news for an extended period in order to protect employment and to minimize litigation concerns (Kothari, Shu and Wysocki, 2009). When accumulated bad news comes out at once in the market, stock prices continue to fall leading to a crash. However, Hong and Stein (2003) developed a model that incorporated heterogeneity in investors' beliefs: one of the key drivers of stock price crash. Investor heterogeneity has the potential to reveal the private signals of relatively pessimistic investors. Observing such signals, other investors could downgrade their assessments of a firm's prospects, thereby reinforcing the decline (Hong and Stein, 2003).

Despite a proliferation of crash risk research with time, there is very little research on the consequences of crash risk. This is rather surprising given that it is crucial to understand firms' responses, including those of the monitors, in order to mitigate future crash risk and to protect shareholders' value. We believe that empirical research on this important issue can make significant contributions to the literature in increasing our understanding of some of those responses and their ultimate success.

In carrying out a systematic review of the determinants and consequences of crash risk, we used two criteria to determine whether to include an article in the review. First we included the search terms "stock price crash," "crash," "negative skewness" and "volatility" to retrieve articles from EBSCOhost, Emerald, Scopus, ProQuest, Science Direct, the Wiley Online Library databases, and Google Scholar. Second, we skimmed through the articles initially derived to identify whether they tested empirically the determinants or consequences of crash risk. Our search procedure returned 41 published studies on the determinants and consequences of crash risk. We did not restrict our search to articles published in a selective list of journals. One 
important consideration for any literature review is whether to include unpublished working papers along with published studies. We excluded working papers from our primary review because (i) the papers have not been adequately vetted by the review process; (ii) it is difficult to identify all working papers, thus exclusion of some of them may generate selection bias; (iii) unpublished papers may be subsequently published. However, to inform readers about the intensity of the research on the determinants of crash risk, we list a large number of working papers in the Appendix (a total of 27 working papers).

We proceed as follows. In the next Section we provide a theoretical overview of crash risk along with the measurement issues, and report descriptive statistics on the primary crash proxies reported in the surveyed studies. In Section 3 we synthesize the literature on the determinants of crash risk. We categorize the determinants into five sections: (i) financial reporting and corporate disclosures, (ii) managerial incentives and managerial characteristics, (iii) capital market transactions, (iv) corporate governance mechanisms, with a particular emphasis on formal governance mechanisms and (v) informal institutional mechanisms. In Section 4 we discuss the empirical research on the consequences of crash risk. Surprisingly, there is very little research attention directed towards this important research question: an observation that motivates us to offer some future research directions. Section 5 concludes the paper.

\section{Stock price crash risk: Theory and measurement}

2.1 Theory of crash risk: We conceptualize crash risk to be a manifestation of extreme negative values in the distribution of firm-specific returns, after adjusting for the return portions that comove with common factors (Jin and Myers, 2006; Kim, Li and Zhang, 2011a,b). Crash risk, a third moment of stock returns capturing negative skewness, is distinct from other measures 
studied in prior research, such as the average return (first moments), and the variance of stock returns (the second moments). Early research on the higher moments of stock returns developed models of expected returns that incorporate skewness (Rubinstein,1973; Kraus and Litzenberger, 1976, 1983). These models predict that higher moments relevant for individual securities comove with the aggregate market portfolio. More recent empirical work provides evidence that higher moments of the return distribution are priced in the market (Conrad, Dittmar, and Ghysels, 2013).

The bulk of the research on the determinants of crash risk follows the theoretical framework proposed by Jin and Myers (2006), who argue that information asymmetry between corporate insiders and outsiders could be related to crash risk (an agency perspective). Conceptually, crash risk is based on the argument that managers have a tendency to withhold bad news for an extended period, allowing bad news to stockpile. If managers successfully block the flow of negative information into the stock market, the distribution of stock returns should be asymmetric (Hutton, Marcus, and Tehranian, 2009; Kothari et al., 2009). While the natural arrival process of new information should not be systematically different between good and bad news, managerial incentives for hoarding bad news can make bad news lumpier than good news. When the accumulation of bad news passes a threshold, it is revealed to the market at once, leading to a large negative drop in stock price (Jin and Myers, 2006). This model, therefore, offers two avenues for enriching the crash risk literature: identifying managerial incentives for hoarding bad news, and the specific mechanism or a set of mechanisms through which such an objective can be accomplished. Both these, however, are challenging for researchers, as managerial incentives are unobservable and researchers are unable to control for many of the potential mechanisms for bad news hoarding. We believe that adequate consideration of these 
challenges is crucial for a meaningful interpretation of the existing empirical findings on the determinants of crash risk.

Two other models, Bleck and Liu (2007) and Benmelech, Kandel, and Veronesi (2010), also follow the agency-based view of crash risk. In the Bleck and Liu (2007) model, historical cost financial reporting allows a manager to continue with a poor investment project, thus receiving compensation prior to the project's maturity. This is facilitated because of outsiders' inability to assess the project's market value until maturity. The Benmelech et al. (2010) model proposes that managers with equity-based contracts continue with negative NPV projects to maximize the value of their compensation packages. Both these models hint towards managerial incentives for hoarding bad news: the precursor for price crash. Eventually, the manager has to disclose the bad news causing a large stock price drop.

Standard agency theory also argues that the existence of information asymmetry between managers and outside stakeholder incentivizes managers to make financial reports more opaque and, hence, to conceal negative information (Hutton et al., 2009). Although financial reporting opacity and its effect on crash risk has become the standard research approach, certain other mechanisms, independent of reporting quality, could also generate price crash. For example, investor heterogeneity has the potential to reveal the private signals of relatively pessimistic investors (Hong and Stein, 2003). This model begins with the observations that a group of investors (e.g., mutual funds) cannot short-sell stocks. Such constraints inhibit the revelation of negative information known to the pessimistic investors in stock prices. However, if other previously optimistic investors exit the market, the former group of investors may become the marginal buyers. Thus previously-hidden bad news surfaces, and results in a price crash. 
Cao, Coval, and Hirshleifer (2002) propose an 'information blockage' model as another theoretical framework for explaining price crash. In this model, an upward price trend prompts favorably informed investors to engage in active trading. In contrast, less informed traders are naturally sceptical about the true nature of the signals and, hence, delay trading until the price drops. Price correction, therefore, is inevitable when the economic outlook becomes pessimistic and the less-informed marginal investors enter the market. Information blockage therefore generates negative returns skewness following price increases but positive skewness following price decreases (Zhu, 2016). Another source of crash risk is volatility feedback effects (e.g., French, Schwert, and Stambaugh, 1987; Campbell and Hentschel, 1992) whereby “...big price movements could cause investors to reassess market volatility and increase required risk premia. An increased risk premium reduces equilibrium prices, which reinforces the impact of bad news but offsets the impact of good news, thus generating negative skewness" (Hutton et al. 2009, p. $68)$.

Finally, the default risk-based explanation for crash risk rests on the notion that firms with higher default risks are more likely to release extremely bad news or extremely good news, because they will either fail or continue as a going concern. Prior literature, used firm size and leverage as proxies for default risk but failed to find support for this proposition. For example, Hutton et al. (2009) and Kim et al. (2011a,b) find a positive relationship between firm size and future crashes, which is counterintuitive, since larger firms are less exposed to bankruptcy risk than smaller firms (Campbell et al. 2008). One plausible explanation of this surprising finding could be attributed to the definition of a price crash, which requires a tail event of sufficient magnitude to fall in the lower $0.1 \%$ of normal distribution (Hutton et al. 2009). As larger firms have lower standard deviations of returns than smaller firms, the absolute magnitude of a return 
needed to qualify as a crash is thus lower for larger firms. Another puzzling finding from the above studies is the negative association between leverage and crash risk, when in reality leverage should be positively associated with bankruptcy risk (Campbell, Hilscher, and Szilagyi, 2008). One potential explanation for this surprising result may be the fact that high leverage firms are initially under-priced by investors, thereby making it less likely that price crashes will follow. Consistent with this explanation, Campbell et al. (2008) show that high leverage firms generate higher future mean returns than low leverage firms (Zhu, 2016, p. 355).

This section summarizes the theoretical underpinnings of crash risk. As is evident from the discussion, researchers predominantly rely on the bad news hoarding argument in explaining crash risk. However, alternative theories need to be empirically tested as well, to ascertain the relative superiority of one framework over another in explaining the occurrence of stock price crash.

\subsection{Measurement of crash risk}

Extant literature uses three measures of firm-specific crash risk, consistent with Chen et al. (2001). These measures are based on the firm-specific weekly returns, estimated as the residuals from the market model. This ensures that crash risk measures reflect firm-specific factors rather than broad market movements. Specifically, the following expanded market model regression is the starting point:

$$
r_{j, \tau}=\alpha_{j}+\gamma_{1},{ }_{j} r_{m, \tau-2}+\gamma_{2},{ }_{j} r_{m, \tau-1}+\gamma_{3},{ }_{j} r_{m, \tau}+\gamma_{4},{ }_{j} r_{m, \tau+1}+\gamma_{5},{ }_{j} r_{m, \tau+2}+\varepsilon_{j, \tau}
$$

Where $r, j, \tau$ is the return of firm $j$ in week $\tau$, and $\mathbf{r}_{m, \tau}$ is the return on the CRSP value-weighted market return in week $\tau$. The lead and lag terms for the market index return is included, to allow for non-synchronous trading (Dimson, 1979). The firm-specific weekly return for firm $j$ in week 
$\tau\left(W_{j, \tau}\right)$ is calculated as the natural logarithm of one plus the residual return from Eq. (1) above. In estimating equation (1), each firm-year is required to have a certain number of weekly stock returns data, to alleviate the thin trading concern.

The first measure is a binary crash risk measure coded 1 if a firm experiences one or more firm-specific weekly returns falling at least 3.09 standard deviations below its mean value in a given year, and zero otherwise. According to Hutton et al. (2009), the cut-off of 3.09 standard deviations is chosen to generate $0.1 \%$ of the distribution. This variable is designed to indicate instances of rather substantial stock price drops in a week.

The second measure of crash risk is the negative conditional skewness of firm-specific weekly returns over the fiscal year $(N C S K E W)$. NCSKEW is calculated by taking the negative of the third moment of firm-specific weekly returns for each year and normalizing it by the standard deviation of firm-specific weekly returns raised to the third power. Specifically, for each firm $j$ in year $\tau, N C S K E W$ is calculated as:

$$
N C S K E W=-\left[n(n-1)^{3 / 2} \sum w_{j, \tau}^{3}\right] /\left[(n-1)(n-2)\left(\sum w_{j, \tau}^{2}\right)^{3 / 2}\right]
$$

The third measure of crash risk is the down-to-up volatility measure (DUVOL) of the crash likelihood. For each firm $j$ over a fiscal-year period $\tau$, firm-specific weekly returns are separated into two groups: "down" weeks when the returns are below the annual mean, and "up" weeks when the returns are above the annual mean. The standard deviation of firmspecific weekly returns is calculated separately for each of these two groups. DUVOL is the natural logarithm of the ratio of the standard deviation in the "down" weeks to the standard deviation in the "up", weeks: 


$$
D U V O L_{j, \tau}=\log \left\{\left(n_{u}-1\right) \sum_{D o w n} w_{j, \tau}^{2} /\left(n_{d}-1\right) \sum_{U p} w_{j, \tau}^{2}\right\} \ldots
$$

A higher value of DUVOL indicates greater crash risk. As suggested in Chen et al. (2001), DUVOL does not involve third moments and, hence, is less likely to be overly influenced by extreme weekly returns.

Kim and Zhang (2014) introduce a new measure, implied volatility smirks, as a proxy for perceived crash risk and validate this measure by documenting a positive association with financial reporting quality, and accounting restatements. The implied volatility of an option contract is the volatility implied by the market price of the option based on an option pricing, e.g., the Black-Scholes model. It is the volatility that equates the Black-Scholes formula to the market price of the option. Kim and Zhang (2014) defined the implied volatility smirk (IVSKEW) as the difference between the implied volatility of OTM puts (IV $\left.{ }^{\text {OTMP }}\right)$ and that of ATM calls $\left(\mathrm{IV}^{A T M C}\right)$ :

$$
\mathrm{IV}-\mathrm{SKEW}=\mathrm{IV}^{\text {OTMP}}-\mathrm{IV}^{A T M C}
$$

Where, OTM puts are defined as put options with a delta value between -0.375 and -0.125 and ATM calls are defined as call options with a delta value between 0.375 and 0.625 . To obtain an annual measure of the volatility smirk, they average the daily $I V$-SKEW over the 12-month period ending three months after the fiscal year-end.

Table 1 provides the descriptive values of the primary crash proxies, and the variation of those values across studies retrieved from the descriptive statistics section of the respective papers. We also report the main variable of interest and its sign, magnitude and the significance level, retrieved from the multivariate analysis Tables.

\section{[TABLE 1 ABOUT HERE]}




\section{Determinants of crash risk: Review of the extant literature}

\subsection{Financial reporting, corporate disclosures, and crash risk 3.1.1 Financial reporting quality and crash risk}

The predominant literature on the determinants of crash risk relies on the theoretical model of Jin and Myers (2006), which naturally required empirical validation. Hutton et al. (2009) addressed this by using accumulated accruals, a proxy for firm-level earnings management, to document that firms with more opaque financial reporting are more prone to price crash. The use of accruals management is justified because such manipulation allows managers to obfuscate at least some information about firm fundamentals. However, research has found that managers have switched from accruals management to real earnings management (REM) in the postSarbanes-Oxley (SOX) period (Cohen, Dey, and Lys, 2008). If REM reflects managerial opportunism as does accruals management, it can be hypothesized that in the post-SOX regime, REM will have greater explanatory power for explaining crash than does accruals. Francis, Hasan and $\mathrm{Li}$ (2014) investigate this proposition and find that firms that engage in REM are prone to crash risk and, importantly, the effect is more pronounced in the post-SOX era. However, a value-enhancing perspective of REM finds that current-period REM improves subsequent performance (Gunny, 2010). Future research should consider this competing perspective, and identify settings where opportunism (informativeness) is better captured by REM actions. For example, Gunny and Zhang (2014) find that firms just meeting analyst forecasts, with many patent citations, have significantly better performance than their counterparts with relatively few patent citations. Future research might use this context and investigate the crash probabilities for firms that meet forecasts with few, as opposed to many, patent citations. 
Besides accruals management and REM, another earnings management tool gaining popularity is 'classification shifting' (McVay, 2006), whereby managers shift some expenses to a 'special item' category to improve core earnings. However, unlike accruals and REM, this technique does not allow managers to withhold bad news. Nevertheless, shifting expenses to boost core earnings is a reflection of lack of transparency: a driver of crash risk. Future research should incorporate a comprehensive reporting quality proxy, including accruals management, REM, and classification shifting, to provide more robust evidence that financial reporting quality is the primary driver of crash risk. Although documenting an association between financial reporting opacity and crash risk is informative, this stream of research does not tell us much about the particular incentives that drive a managerial decision to withhold bad news. We now review the strand of research that addresses this concern.

\subsubsection{Executive compensation and price crash}

An oft-cited incentive for earnings management and, hence, asymmetric disclosure of news, is to maximize the incentives-based compensation. Kim et al. (2011a) investigate the relative contribution of $\mathrm{CEO}$ versus $\mathrm{CFO}$ equity incentives for crash risk, and find that the ratio of the CFO option portfolio value to stock price increases the crash risk. Since CFOs oversee the financial reporting process, their incentives might be more influential in a decision setting where sophisticated financial expertise is required to manipulate information flows to the market (Jiang, Petroni, and Wang, 2010; Chava and Purnanandam, 2010). If blockage of negative information stemming from CFO incentives has adverse implications for shareholders, then why wouldn't firm-level corporate governance mechanisms constrain such action? The authors considered an external governance mechanism, product market competition, but not internal governance tools. 
This creates an omitted variable problem, the impact of which, based on the documented results, is not known. He (2015) investigates the impact of another form of compensation: CEO inside debt. Inside debt refers to debt in the form of pensions and deferred compensation that resembles debt contracts, representing a fixed obligation for a firm to make future payments to CEOs. The general consensus from the literature is that inside debt motivates managers to commit to highquality financial reporting. Consistent with this argument, He (2015) finds that inside debt reduces future price crash.

\subsubsection{Tax avoidance and crash risk}

The aggregate earnings management proxy, however, has a limitation. This measure fails to document the specific methods and/or combination of methods used by managers to manage earnings. One such technique for managing earnings and, thereby, withholding bad news is corporate tax avoidance. Kim et al. (2011b) find that corporate tax avoidance increases crash risk, supporting the contention that aggressive tax strategies and planning provide managers with a means to conceal negative information, thereby increasing crash risk. However, auditorprovided tax services constrain tax expense management and tax avoidance (knowledge spillover benefits), thereby reducing the propensity for crash (Habib and Hasan, 2016). However, Choudhary, Koester, and Pawlewicz (2015) find that tax accrual quality, a measure of financial reporting quality specific to the tax account, decreases in firms where incumbent auditors also provide tax services. An avenue for future research would be to test whether tax accrual quality affects crash risk, and whether auditor-provided tax services moderate the association between the two. 


\subsubsection{Accounting conservatism, financial statement comparability and readability, and crash risk}

Given the widespread use of earnings manipulation (Graham, Harvey \& Rajgopal, 2005) and its adverse effects on crash risk with direct consequences for investors, it becomes imperative to understand the financial reporting-related mechanisms for constraining such opportunistic reporting behavior and, hence, crash risk.

Conditional conservatism, a desirable attribute of financial reporting (Basu, 1997; Watts 2003 a, b; Ball and Shivakumar, 2005) is one such constraint. Conservatively-audited earnings attenuate (accelerate) managerial incentives to release positive (negative), but unverifiable, information. Timely disclosures of bad news reduce crash risk. Using conservative accounting policy that offsets managers' tendencies to hide bad news as the informational setting, Kim and Zhang (2015) find that crash risk decreases for firms with more conservative accounting policies.

Financial statement comparability ${ }^{2}$, another desirable characteristic of financial reporting, has also been found to attenuate crash risk ( $\mathrm{Kim}, \mathrm{Li}, \mathrm{Lu}$ and $\mathrm{Yu}, 2015)$. This is premised on the following argument:

"By having access to and being able to understand information from comparable firms, investors can not only gain a better understanding of a firm's performance but also obtain some of the bad news about it through inferences based on the performance and/or disclosures of its comparable peers... Since investors may have already obtained some of the undisclosed bad news about a firm by analyzing its comparable peer firms, the benefits to managers from bad news hoarding are likely to be smaller..." (Kim et al., 2016, p.295).

\footnotetext{
${ }^{2}$ An intuitive definition of comparability rests on the notion that "...the accounting system is a mapping from economic events to financial statements. For a given set of economic events, two firms have comparable accounting systems if they produce similar financial statements." (DeFranco, Kothari, and Verdi, 2011, p. 896). Since comparability reflects similarities in the operating environment as well as in financial reporting behavior with other firms, the degree of comparability is mainly determined by common economic factors and firm-specific factors (Zhang, 2013). While common economic factors affect firms within the same industry in a similar way and, thus, increase comparability, firm-specific factors, such as financial or operating characteristics and disclosure systems, may reduce comparability.
} 
Although external stakeholders would benefit from more comparable financial information, there are also likely to be significant proprietary costs of comparability in the face of intense competition. This occurs because managers rely on information from their competitors' financial reports as inputs to developing their competitive strategies (e.g., Bagnoli and Watts, 2010; Beatty, Liao, and Yu, 2013). Consequently, managers of firms operating in competitive industries would have incentives to lessen financial statement comparability. Seavey, Imhof and Watanabe (2016) find support for this proposition. It would be interesting to explore whether firms operating in highly competitive industries are more likely to experience crash risk given the supply of less comparable financial statements.

The information contained in the annual reports, although of paramount importance, is plagued with serious concerns about the readability of those reports (SEC, 1998). In terms of economic consequences of the less readable annual reports, Ertugrul, Lei, Qiu and Chi (forthcoming) find that firms with larger 10-K file sizes, and a higher proportion of uncertain and weak modal words in $10-\mathrm{Ks}$, are associated with greater crash risk.

\subsubsection{Internal control weakness and crash risk}

The extent to which the above-discussed mechanisms are effective in curbing crash risk depends a lot on the internal control quality level in an organization. For example, a weak control environment has the potential to allow both intentional misreporting through accruals manipulation, and unintentional errors in accrual estimation. Taken together, firms with ineffective internal control, in particular, internal control over financial reporting, disseminate less reliable financial information (Doyle, Ge, and McVay 2007a, b; Ashbaugh-Skaife, Collins, Kinney, LaFond, 2009; Feng, Li, and McVay, 2009): the primary driver of crash risk. Chen, Chan, Dong and Zhang (2016) focus on the strength of internal control of Chinese listed firms, 
and find that high quality internal control alleviates crash risk. The quality of internal control is measured with a composite index evaluated on five components (i.e. control environment, risk assessment, control activities, information and communication and monitoring). ${ }^{3}$

Besides financial reporting-related constraining mechanisms, non-reporting mechanisms, e.g., corporate governance mechanisms, play a crucial role in minimizing crash risk. We discuss this stream of research in Section 3.7. We also believe that important insights can be gained by investigating firm-level strategic choices, including customer concentration, on crash risk. Research on the financial reporting implications of customer concentration has revealed that supplier firms with a concentrated customer base manage earnings through the opportunistic use of accruals (Bowen, DuCharme, and Shores, 1995; Raman and Shahrur, 2008), report conservatively (Hui, Klasa, and Yeung, 2012), and make less frequent earnings forecasts (Crawford, Huang, Li, and Yang, 2016). Since all these variables have been found to be related to crash risk, future research should investigate relationship-induced reporting practices on crash risk.

\subsection{Voluntary disclosures and crash risk}

Managers may also use voluntary disclosures opportunistically to conceal bad news for an extended period. However, such disclosures can also reduce information asymmetry, and lessen

\footnotetext{
${ }^{3}$ Since 2006, China has been strengthening its internal control regulations. The Basic Standard, known as the China SOX, became effective on 1 July 2009. The Basic Standard requires listed firms to strengthen their internal control over the following five aspects, namely, the internal control environment, internal risk assessment and management, internal control activities, internal control information disclosure and communication, and internal control oversight (Ministry of Finance, 2008). After that, the Internal Control Application Guidelines issued in April 2010 provide detailed instructions on how the Basic Standard is to be fully implemented. As complementary regulations to strengthen internal control monitoring, the Internal Control Evaluation Guidelines and the Internal Control Audit Guidelines stipulate listed firm's self-evaluation on their internal control effectiveness in relation to the five aspects and the responsibilities required on auditors (Ministry of Finance, 2010).
} 
the need for bad news hoarding. Corporate social responsibility disclosures (CSR) are one such voluntary disclosure tool. Prior empirical evidence documents that, among other benefits, socially responsible firms provide more and better financial disclosures (Gelb and Strawser, 2001) and engage less in earnings management (Kim, Park and Weir, 2012). Building on this premise, Kim et al. (2014) reveal that firms with better CSR disclosures have a lower crash risk. However, they did not test some of the channels through which the beneficial effects of CSR on crash risk can be manifested. Zhang, Xie and Xu (forthcoming) examine the effects of corporate philanthropic action (a component of CSR) on crash risk in China, and find that corporate philanthropic action reduces crash risk. However, the negative association is less pronounced for SOEs, and is also less pronounced after the 2007 split share reform act. ${ }^{4}$

\subsection{Accounting standards and crash risk}

From an accounting standards perspective little research has examined the impact of accounting standards on crash risk. Although mandatory, accounting standards need to allow flexibilities and, hence, open up an avenue for inconsistent application at best, and earnings manipulation and reporting fraud at worst. Such flexibilities, therefore, allow managers to conceal negative information, particularly with the onset of a fair value-based reporting regime. DeFond, Hung, and Li (2015) is the only available study that investigates the impact of accounting standards on crash risk. They find that the adoption of International Financial Reporting Standards (IFRS) has reduced crash risk among nonfinancial firms. This effect is more pronounced for those with large information asymmetry during pre IFRS adoption, and a more credible change in local GAAP post adoption. It is important to note that IFRSs vary, in terms of their degree of complexity and, hence, the opportunities for withholding bad news. Therefore, the development of a more refined

\footnotetext{
${ }^{4}$ See Jiang and Habib (2012) for a background discussion on the 'split share reform initiative in China.
} 
proxy to determine firm-level variation in IFRS complexity and its impact on crash risk remains an open empirical question. Mergenthaler (2012) develops an instrument that measures the extent to which a standard contains rules-based characteristics (RBC). One may sort firms according to their use of the RBC, and investigate whether greater RBC leads to higher price crash.

A shortcoming of the extant empirical research relating crash risk to managerial opportunistic reporting incentives concerns the absence of a causal test to determine whether incentives lead to crash risk through the bad news hoarding channel. For example, managerial incentives to engage in upward earnings management due to compensation incentives are welldocumented in the literature. However, a causal test would require decomposing the effects into direct effects of incentives as a proportion of crash risk and indirect effect of specific channels, e.g., opaque reporting, as a proportion of crash risk. However, such a test is missing from the existing literature. To give an example, Kim et al. (2011a) included compensation proxies as the main variable of interest and controlled for abnormal accruals instead of interacting the two.

Similar arguments apply in relation to Kim et al.'s (2014) study on CSR and crash risk. The negative coefficient on CSR in itself does not inform readers about the bad news hoarding theory. It is therefore important to examine the channels through which CSR curbs bad news hording and crash risk. It has also been found that CSR firms engage less in tax avoidance (Lanis and Richardson, 2012) and tax avoidance increases crash risk (Kim et al. 2011b), implying another possible moderating variable that may explain the CSR-crash relationship. It is important that future research provides explicit tests to isolate the direct and indirect contribution of chosen variables to crash risk. 


\subsection{Managerial characteristics and crash risk}

Do managerial traits or styles have implications for crash risk? This line of enquiry is important because it is the idiosyncratic characteristics of managers that shape their decision choices regarding the withholding of bad news: the primary predictor of crash risk. Kim, Wang, and Zhang (2014) consider 'CEO overconfidence' as one such managerial trait, and find that overconfident CEOs are more likely to experience stock crash. This finding is in line with the argument that overconfident CEOs are more likely to keep alive negative NPV projects because of their biased overestimation of future cash flows. An overconfident CEO also tends to ignore negative feedbacks originating from value-destroying negative NPV projects. The poor performance of these bad projects accumulates and eventually is released to the market all at once, leading to a stock price crash. Are overconfident managers also talented managers? Demerjian, Lev, Lewis, McVay (2013) reveal that more-able managers provide better quality earnings and, thus, should reduce the propensity for crash. However, more-able managers could also be overconfident and, hence, entangling these two constructs in order to infer their relative contribution to crash risk would be a valuable contribution to the crash literature.

Nonetheless, a direct association between managers and crash risk requires the development of a manager's fixed effects model: tracking managers who move across firms. Researchers also need to incorporate firm fixed-effects to solidify the direct association between managers and crash risk. We encourage further research on this important 'human dimension' to explain crash risk. Moreover, like individual CEOs, individual auditors have styles (Francis, Pinnuck, and Watanabe, 2014). Future research may examine whether auditor fixed-effects affect crash risk. 


\subsection{Capital market determinants of crash risk}

While studies predominantly contend that stock price crash occurs when accumulated bad news is released all at once in the capital market, some studies document that such bad news hoarding may be reflected in stock trade volume and return: an observation that could provide reasonable indication about future price crash. For example, Chen et al. (2001) argue that trade volume reflects disagreement among investors and, as such, an increase in trading volume relative to trend over the prior six months indicates that some investors are aware of pending bad news, resulting in higher trading between informed and uninformed investors. They also contend that positive returns over the prior 36 months imply that a bubble has been building up for a long time, which is naturally followed by a by a large drop in stock price when prices fall back to fundamentals. Consistent with their argument, Chen et al. (2001) find that crash risk is more pronounced for stocks that experienced large trading volumes and high past returns.

In addition, studies also show that the capital market itself provides an incentive to hoard bad news, which increases the likelihood of future price crash. For example, in a recent study Chang, Chen and Zolotoy (Fortjhcoming) use stock liquidity to proxy for such an incentive, and find that the probability of future crash risk increases with an increase in stock liquidity. Their empirical evidence is consistent with the argument that stock liquidity provides a managerial incentive to withhold bad news, fearing that bad news disclosures may lead transient investors to sell their stock. While Chang et al. (2016) show empirically that the effect of stock liquidity on future crash risk is more pronounced for firms with a high proportion of transient institutional ownership, the extent to which stock liquidity affects crash risk directly and indirectly (through the transient investor channel) is not clear from their analysis. Therefore, future research may investigate the direct, indirect and total effect of stock liquidity on future price crash. Callen and 
Fang (2015), document that short interest in stocks predicts future crash risk. This is consistent with the view that short sellers are able to detect managerial bad news hoarding activities, prompting them to take short positions of stock in anticipation of price crashes.

\subsection{Corporate governance and crash risk}

3.6.1 Internal corporate governance mechanism and crash risk

Corporate governance attributes have an important role on financial disclosure and reporting quality (Larcker, Richardson, and Tuna 2007). For example, Bedard, Chtourou, and Courteau (2004) show that the financial and governance expertise of audit committee members reduces aggressive earnings management. Xie, Davidson, and DaDalt (2003) also provide consistent evidence that board and audit committee activity and their members' financial sophistication, have a crucial impact on constraining the managerial propensity to engage in earnings management. Extending these findings to crash risk, Andreou, Antoniou, Horton, and Louca (2016) show that a high proportion of independent directors on the audit committee, adequate auditor industry expertise, and a clearly-defined corporate governance policy, reduce the likelihood of crash.

Prior research on stock price crash risk in China has investigated some of the determinants of crash risk including excess perks in State Owned Enterprises (SOEs). Xu, Li, Yuan, and Chan (2014) report that excess perks in SOEs motivate managers to withhold bad news over extended periods for personal gain, resulting in a high crash risk. Meanwhile, they find that low financial reporting quality, i.e., earnings management and a low level of conservatism, worsens this relation. 


\subsubsection{External corporate governance mechanisms and crash risk}

In this section we review the role of external corporate governance mechanisms in mitigating crash risk. We consider institutional holding, large shareholdings, financial analysts, external auditing, and the director and officer liability $(\mathrm{D} \& \mathrm{O})$ insurance as some of the governance mechanisms. Extant studies suggest that monitoring by the institutional owners constrains a manager's ability to manage abnormal accruals opportunistically and, hence, improves earnings quality (e.g., Mitra and Cready, 2005; Velurya and Jenkins, 2006). Since better quality earnings reduce crash risk, research examines the effect of institutional monitoring on crash risk. An and Zhang (2013) show that institutional holding by dedicated (transient) investors reduces (increases) crash risk. However, they do not show the channel(s) through which both classes of institutional shareholding may affect crash risk. In a similar study, Callen and Fang (2013) show that institutional investor stability is associated negatively with crash risk. However, in their study the moderating role of opacity in affecting crash risk is not convincing, as the interaction between opaque financial reporting and institutional stability is largely insignificant.

Studying the separation of voting and cash flow rights (excess control) of French listed firms, Boubaker, Mansali and Rjiba (2014) report a positive relation between excessive control and stock price crashes, which is consistent with their argument that controlling shareholders with excessive control tend to withhold bad news in order to cover up their expropriation of minority shareholders' interest. Andreou et al. (2016), on the other hand, find insignificant (significant) effects of outside block shareholdings (insider ownership) on crash risk.

Financial analysts play an important role in revealing firm-specific information, which has valuable implications for crash risk. Using Chinese data, Xu, Chan, Jiang, and Yi (2013) find that stock price crash risk increases with an increase in a firm's analyst coverage, and this is more 
pronounced when analysts are more optimistic, and are affiliated with investment banks and brokerage firms.

It is well-established in the literature that Big audit firms and industry specialist auditors play important roles in improving the financial reporting quality and curbing managerial incentives to manage earnings for opportunistic purposes (Becker, DeFond, Jiambalvo, and Subramanyam, 1998; Krishnan, 2003; Balsam, Krishnan, and Yang, 2003). Robin and Zhang (2015) find that the information intermediary and corporate governance roles of the auditor industry specialization reduce crash risk. They also show the channels (e.g., opacity, accounting conservatism, and tax avoidance) through which industry specialist auditors reduce the crash risk. Callen and Fang (2016) show that auditor tenure enhances auditors' client-specific knowledge, which reduces future stock price crash risk. The evidence is consistent with the argument that development of client-specific knowledge over audit tenure enhances auditors' ability to detect and deter bad news hoarding activities by clients, thus reducing future crash risk.

The D\&O insurance, which incorporates D\&O insurance underwriters' forward-looking assessment of a company's litigation likelihood and damage magnitude, can be viewed as a continuous, ex ante measure of litigation risk. Firms purchase D\&O insurance coverage for reimbursement of directors' and officers' defense costs and settlements arising from litigation (Cao and Narayanamoorthy, 2011, 2014). Yuan, Sun, and Cao (2016) investigate the effect of D\&O Insurance on crash risk using data from Chinese listed companies. They argue that D\&O insurers serve as an external monitoring mechanism, owing to weak corporate governance at firm-level and poor investor protection at country-level. As expected, they find a negative association between D\&O Insurance and crash risk. Their additional tests also show that firms purchasing D\&O insurance tend to have a low likelihood of financial restatements and great 
corporate social responsibility reporting. It is noteworthy that, although this study makes a significant improvement in attempting to propose two economic mechanisms through which D\&O insurance reduces crash risk, the tests are only conducted to establish a link between D\&O insurance and earnings quality and CSR reporting rather than to test whether the effect of D\&O insurance on crash risk still holds after controlling for earnings quality and firms' voluntary disclosures.

Collectively, studies on the effect of corporate governance and external auditing on stock price risk via their effect on firms' financial reporting quality are intuitive and theoretically coherent. The findings conform to two streams of literature, including (1) the Corporate governance attributes and external monitoring mechanisms that shape financial disclosures and reporting quality (Larcker et al., 2007); (2) Jin and Myers's (2006) theory on bad news hoardinginduced crash risk, and corresponding empirical evidence that firms with more opaque financial reporting are more prone to price crash (e.g., Hutton et al. (2009).

\subsection{Non-formal institutions and crash risk}

The preceding section summarized the literature on the formal governance mechanism (both internal and external) of crash risk. In this section, we review the impact of non-formal institutions on crash risk.

\subsubsection{Political connections and crash risk}

We begin with a recent study that examines the association between political connections and crash risk. There remains controversy as to whether political connections are beneficial or detrimental to stakeholder interests. Evidence (Fisman, 2001) supporting the beneficial effects of 
political connections reveals that such connections enhance firms' value, among many other benefits. On the other hand, studies also show that political connections are harmful to minority interests. Empirical research documents that politically connected firms usually undertake high rent-seeking activities, e.g., tunnelling (Boubakri, Guedhami, Mishra, and Saffar, 2012; Faccio, 2006).

Lee and Wang (forthcoming) use data from China and document that the presence of politically connected directors accentuates crash risk in listed SOEs, courtesy of appointment of local government officials as directors. In contrast, appointment of central-government-affiliated directors helps listed privately-controlled firms to reduce crash risk. ${ }^{5}$ Piotroski, Wong and Zhang, (2015) conjecture that political events in China create incentives for listed companies to withhold bad news, because politicians and executives of listed companies incur large costs and strong penalties for releasing negative news around politically sensitive events. As expected, they find that both SOE- and non-SOE listed companies time bad news disclosure strategically, showing significantly lower (greater) likelihood of experiencing stock price crash risk before (after) two major political events: meeting of the National Congress and provincial-level political promotions. The findings highlighting political events stand as a distinct determinant of firms' bad news hoarding behavior. Li and Chan (2016) examine whether Communist Party of China (CPC) control affects crash risk. They argue that CPC control can restrain executives from hiding bad news and, thus, firms' information flows to the market become orderly, lowering crash risk. The findings support this conjecture, showing that having a CPC committee member serving as a director can lower a firm's crash risk. However, the effect of political intervention is a complex issue, and it is far from clear whether political parties' interference with corporate

\footnotetext{
${ }^{5}$ Central-government-controlled firms have a stronger incentive than local-government-controlled firms to pursue shareholder value maximization as is evident, among others, from the requirement for the former to adopt earnings-based compensation contracts [Ke, Li \& Yuan (forthcoming)].
} 
issues is beneficial or detrimental to shareholders' wealth. For instance, Chang and Wong (2004) report that $\mathrm{CPC}$ control damages a firm's accounting performance, but restrains expropriation by large shareholders. Due to this complexity, explaining the effect of the CPC from an information-hoarding perspective only, as proposed in this paper is insufficient and unconvincing.

\subsubsection{Religiosity and crash risk}

Another informal institution having implications for crash risk is religion. Callen and Fang (2016) find that crash risk is lower for firms headquartered in counties in the USA with higher levels of religiosity, supporting the argument that religion as a social norm constrains managerial bad news hoarding incentives. The authors propose that "...religious managers are more likely to internalize the social norms associated with antimanipulation and so are less likely to manipulate the flow of corporate information... [they] also consider the cost in terms of social stigma if they are caught violating social norms by manipulating the flow of corporate information..." (p. 170). However, the negative association is more pronounced for firms with lower ownership by dedicated institutions, with weaker shareholder takeover rights, and for riskier firms. Li \& Cai (forthcoming) also examine the effects of religion on crash risk in China. An impressive aspect of their research is that they conduct formal tests of the channels through which the religion-crash risk relationship could manifest itself. They find that religion indeed reduces crash risk, and this occurs primarily through constraints on earnings management and perk consumption. Finally, they find that the negative relationship between religion and crash risk is more pronounced when the quality of corporate governance, and of the legal environment, is higher. This seems counterintuitive, since the role of religion is likely to be stronger where 
formal institutions are weaker. The authors, however, did not provide any justification for their findings. Research on the impact of religion on crash risk considers broader religious beliefs as manifested at the state/county level. However, it would be also important to consider the individual religious beliefs of the executives (e.g., CFOs) and auditors who are in charge of the financial reporting process. It is therefore imperative to investigate whether it is the religious beliefs of individuals, or the broader social norm, that plays the pivotal role in constraining the bad news hoarding tendency.

\subsubsection{Monitoring ability of the regulatory authorities and crash risk}

Kubick and Lockhart (2016) examine the effects of SEC oversight on managerial disclosure practices having implications for crash risk. They find that firms located farther from the SEC headquarters experience greater crash risk. This association is more pronounced for firms with more complex financial statements, and when SEC budgets are relatively smaller. This is theorized on the notion that managers have subjective estimates regarding the probability of being investigated by SEC officials, emanating from their disclosure practices. Managers who believe that enforcement of disclosure violations is less likely, due to their office being farther away from the SEC, will follow an asymmetric information release policy for negative and positive information, hence increasing the probability of crash risk. However this may not be a concern for investors if religion plays a constraining role (Callen and Fang, 2016). What happens when firms farther from the SEC headquarters operate in counties with higher levels of religiosity? How would the result of Kubick and Lockhart (2016) change if religion were used as an independent variable? 


\subsubsection{Other non-formal institutions and crash risk}

Aman (2013) investigates the associations between media coverage and stock price crashes and jumps using data from Japanese stock markets and newspaper articles. The findings suggest that media coverage does not affect the price jumps, but has an increasing effect on crashes. This crash-inducing effect of media coverage is due to extremely large reactions to information distribution among investors as a result of concentrated media coverage. Ben-Nasr, Al-Dahmash \& Ghouma (2015) examine the influence of labor unionization on crash risk, and find a positive association between the two. This finding is consistent with the argument that firms facing strong labor unions tend to report lower accounting information, in order to preserve bargaining power when negotiating contracts with labor unions. However, the labor union effects on crash risk are less pronounced for firms with strong external monitoring mechanisms, e.g., high institutional ownership and high analyst coverage.

In this section we reviewed an interesting aspect of the determinants of crash risk: the impact of informal institutions. Although research abounds on formal governance institutions (for example, director, audit and compensation boards), institutional ownership and external auditing, literature on the more implicit governance institutions has the potential to offer more interesting insights. In particular, it will be important to understand the substitutive, versus the complementary, relationships between these two groups of institutions.

\subsection{Financial institutions and crash risk}

The association between financial reporting opacity and crash risk has also been documented for financial institutions. Cohen et al. (2014) find that earnings management (proxied by discretionary loan loss provisions and/or by discretionary realizations of security gains or losses) 
accentuates crash risk for banks during crisis but not during periods of economic boom. Using data from 37 countries, Song, Du and Wu (2016) also find that banks experience lower crash risk if their information environment is more transparent. Given the role of the banking sector in allocating resources to economies around the world, we suggest more crash-related research for financial institutions.

Table 2 summarizes the research questions, sample(s) used, and key findings for some key research papers on the determinants of crash risk. We also report whether the selected studies justified their choice of a particular sample period and explained the economic significance of the reported coefficients on the main variable of interest [Dyckman \& Zeff (DZ), 2014]. With respect to the former issue, DZ found only 10 out of the 55 regression papers reviewed provided some kind of justification for the selection of the particular sample period. In our case, we find 14 out of 28 studies included in Table 2 justify their chosen sample period. Although better than that reported by DZ, there is much room for improvement for the present and future crash risk researchers to make explicit their rationale for choosing a particular sample period. We also include a column titled "Economic significance of the coefficient of interest". This is very important, since "A statistically significant result is not necessarily an important result. Without establishing the economic importance of the result, which requires additional work on the part of the researcher, the mathematics reported to date is worthless" (DZ, 2014, p. 703). We find that 18 out of the 28 studies included in the Table report the economic as well as the statistical magnitude of their findings.

\section{[TABLE 2 ABOUT HERE]}




\subsection{Consequences of crash risk}

Although research initiatives designed to understand the causes of crash risk are plentiful, our review revealed only two published studies on crash consequences. We find this surprising. Following the incidence of crash, which has serious implications for shareholders' wealth, we would expect firms willingly, and/or because of the pressures crated by various stakeholders, to take some initiatives to minimize some of the drivers of price crash. ${ }^{6}$ For example, if earnings manipulation is responsible for crash, will there be more effective oversight on the financial reporting process by the audit committees during the post-crash period? If CEO and CFO equity incentives are responsible for crash risk, would the compensation committee consider redesigning compensation schemes? Answers to these questions are not simple. Although equity incentives have been identified as a determinant of crash risk (Kim et al., 2011a), it is difficult for researchers to control for all other determinants, some of which may well be beyond CEO control, e.g., political turmoil. An unintended consequence of reducing equity incentives due to crash could lead managers to pass on risky but positive NPV projects.

Of the two published papers, An, $\mathrm{Li}$, and $\mathrm{Yu}$ (2015) investigate the impact of crash risk on a firm's speed of leverage adjustment, and how this effect is moderated by the information environment. Using data from 41 countries from 1989 to 2013, they show that firms with a higher crash-risk exposure slowly adjust their financial leverages toward targets. They also show that the negative relation between crash risk and speed of leverage adjustment is less pronounced for firms in countries with more transparent financial reporting environments. Hackenbrack, Jenkins, and, Pevzner (2014) document a 2 percent increase in clients' audit fees, ahead of a

\footnotetext{
${ }^{6}$ Although not linked to crash risk, Farber (2005) finds that SCE-alleged fraud firms take actions to improve their governance and succeed in doing so, as their governance characteristics become similar to the control firms. Farber also finds that the capital market values governance improvement, as firms that take actions to improve governance have superior stock price performance.
} 
price crash occurring. The finding suggests that a significant portion of the mean increase in audit fees is due to an increase in the auditor's perception of idiosyncratic risk, proxied by crash risk.

We also searched for working papers on the consequences of price crash, although we had not reviewed working papers on the determinants of crash risk. This departure was necessitated by a paucity of research on consequences of crash. Wu (2013) documents a positive association between current-period crash risk and CEO turnover in the subsequent year, an effect which is more pronounced for forced turnover. The findings also suggest that boards of directors react by removing CEOs for poor performance: a driver of crash risk. Further research needs to document labor market penalties for directors of crash firms as well. Srinivasan (2005) finds that in the three years after restatement, director turnover is $48 \%$ for firms that restate earnings downward. Since earnings restatement signals lack of monitoring of the financial reporting process, which could cause crash risk, future research needs to show that labor market penalties exist for directors of crash firms.

Another interesting avenue for future research on crash risk consequences would be to examine post-crash investment behavior, including CEO risk-taking, in crash firms. If overinvestment leads to crash risk, the might then be assumed that firms would adjust their investment policies towards the optimum level following a crash. Since research has found that overconfident CEOs are more prone to overinvestment compared to their diffident counterparts (Malmendier and Tate, 2005; Lin, Hu, and Chen, 2005; Huang, Jiang, Liu, and Zhang, 2011) replacing overconfident CEOs post-crash may be an effective remedy. But Goel and Thakor (2008) show that in a tournament setting, overconfident managers are more likely to become executives because they perceive less risk and therefore take more chances. So failure to find that 
high removal rates of overconfident CEOs post-crash does not necessarily imply governance failure.

Taken together, we believe that there is immense potential for future research in the areas of crash risk consequences. We have outlined some of the areas where research attention can be directed and proposed some hypotheses that can be tested empirically.

\section{Conclusion}

In this paper we reviewed the empirical literature on the determinants and consequences of stock price crash risk. We categorize the determinants into (i) financial reporting and corporate disclosures, (ii) managerial incentives and managerial characteristics, (iii) capital market transactions, and (iv) formal and informal corporate governance mechanisms.

Managerial incentives for hoarding bad news have been the primary focus of the burgeoning literature on crash risk. However, incentives alone would not be sufficient to withhold bad news. Managers would have to devise mechanisms for concealing negative information. Earnings manipulation (both accruals and real), tax avoidance, and voluntary disclosures (CSR disclosures and management earnings guidance) have been identified as some of the mechanisms used by managers. Finally, reporting conservatism, external auditing, and corporate governance mechanisms (e.g. institutional monitoring) can curb managerial opportunistic use of mechanisms for concealing negative information.

Finally, in terms of country coverage on the determinants of crash risk research, we note with no surprise that USA dominates the empirical research followed by China. Although there are a couple of international studies, we were surprised to find no published study on either crash risk determinants or consequences of crash from other parts of the world. Of course, inferences 
may be similar for countries with institutional environments similar to the US, e.g. the UK, Australia, and Canada; and this may restrain researchers from pursuing research on crash risk in other similar institutional settings. Yet it is well known that, despite the institutional similarities, similar research questions or some variants thereof have been pursued across these countries. Therefore, we call for more research in an international context to better understand the effect of country-specific idiosyncratic features on the determinants and consequences of price crash. 


\section{References}

Aman, H. (2013). An analysis of the impact of media coverage on stock price crashes and jumps: Evidence from Japan. Pacific-Basin Finance Journal, 24 , 22-38 .

Amihud, Y., Mendelson, H., \& Wood, R. A. (1990). Liquidity and the 1987 stock market crash. The Journal of Portfolio Management, 16(3), 65-69.

An, Z., Li, D., \& Yu, J. (2015). Firm crash risk, information environment, and speed of leverage adjustment. Journal of Corporate Finance 31, 132-151.

An, H., \& Zhang, T. (2013). Stock price synchronicity, crash risk, and institutional investors. Journal of Corporate Finance, 21, 1-15.

Andreou, P.C., Antoniou, C., Horton, J., \& Louca, C. (2016). Corporate governance and firm-specific stock price crashes. European Financial Management, Forthcoming.

Ashbaugh-Skaife, H., Collins, D., Kinney, W., LaFond, R. (2009). The effect of SOX internal control deficiencies and their remediation on accrual quality. The Accounting Review 83, 217-250.

Bagnoli, M., \& Watts, S. G. (2010). Oligopoly, disclosure, and earnings management. The Accounting Review, 85 (4), 1191-1214.

Balsam, S., Krishnan, J., \& Yang, J. S. (2003). Auditor industry specialization and earnings quality. Auditing: A Journal of Practice \& Theory, 22(2), 71-97.

Ball, R., \& Shivakumar, L. (2005). Earnings quality in UK private firms: Comparative loss recognition timeliness. Journal of Accounting and Economics, 39(1), 83-128.

Basu, S. (1997). The conservatism principle and the asymmetric timeliness of earnings. Journal of Accounting \& Economics, 24 (1), 3-37.

Beatty, A., Liao, S., \& Yu, J. J. (2013). The spillover effect of fraudulent financial reporting on peer firms' investments. Journal of Accounting \& Economics, 55 (2-3), 183-205.

Becker, C. L., DeFond, M. L., Jiambalvo, J. \& Subramanyam, K. (1998). The effect of audit quality on earnings management. Contemporary Accounting Research, 15(1), 1-24.

Bedard, J., Chtourou, S. M., \& Courteau, L. (2004). The effect of audit committee expertise, independence, and activity on aggressive earnings management. Auditing: A Journal of Practice \& Theory, 23(2), 13-35.

Benmelech, E., Kandel, E., \& Veronesi, P. (2010). Stock-based compensation and CEO (dis) incentives. The Quarterly Journal of Economics, 125(4), 1769-1820.

Ben-Nasr, H., Al-Dahmash, A., \& Ghouma, H. (2015). Do labor unions affect stock price crash risk? International Journal of Financial Research, 6(2), 11-22.

Bleck, A., \& Liu, X. (2007). Market transparency and the accounting regime. Journal of Accounting Research, 45(2), 229-256.

Boubaker, S., Mansali, H., \& Rjiba, H. (2014). Large controlling shareholders and stock price synchronicity. Journal of Banking \& Finance, 40, 80-96.

Boubakri, N., Guedhami, O., Mishra, D. \& Saffar, W. (2012). Political connections and the cost of equity capital. Journal of Corporate Finance, 18, 541-559.

Bowen, R.M., DuCharme, L. \& Shores, D. (1995). Shareholders' implicit claims and accounting method choice. Journal of Accounting and Economics 20(3), 255-295.

Cao, Z., \& Narayanamoorthy, G. S. (2011). The effect of litigation risk on management earnings forecasts. Contemporary Accounting Research, 28(1), 125-173.

Cao, Z., \& Narayanamoorthy, G. S. (2014). Accounting and litigation risk: Evidence from directors' and officers' insurance pricing. Review of Accounting Studies, 19, 1-42.

Callen, J. L., \& Fang, X. (2016). Crash risk and the auditor-client relationship. Contemporary Accounting Research, Forthcoming.

Callen, J. L., \& Fang, X. (2013). Institutional investor stability and crash risk: Monitoring versus shorttermism?. Journal of Banking \& Finance, 37(8), 3047-3063. 
Callen, J. L., \& Fang, X. (2015). Short interest and stock price crash risk. Journal of Banking \& Finance, 60, 181-194.

Callen, J.L., \& Fang, X. (2015). Religion and stock price crash risk. Journal of Financial and Quantitative Analysis, 50 (1\&2), 169-195.

Campbell, H.R., \& Siddique, A. (2000). Conditional skewness in asset pricing tests. Journal of Finance 55, 1263-1295.

Campbell, J.Y., \& Hentschel, L. (1992). No news is good news: an asymmetric model of changing volatility in stock returns. Journal of Financial Economics 31, 281-318.

Campbell, J., Hilscher, J., \& Szilagyi, J. (2008). In search of distress risk. The Journal of Finance, 63(6), 2899-2939.

Cao, H., Coval, D., \& Hirshleifer, D. (2002). Sidelined investors, trading-generated news, and security returns. Review of Financial Studies, 15(2), 615-648.

Chang, X., Chen, Y., \& Zolotoy, L. (2016). Stock liquidity and stock price crash risk. Journal of Financial and Quantitative Analysis (Forthcoming).

Chang, E.C., \& Wong, S.M.L. (2004). Political control and performance in China's listed firms. Journal of Comparative Economics, 32, 617-636.

Chava, S., \& Purnanandam, A. (2010). CEOs versus CFOs: incentives and corporate policies. Journal of Financial Economics 97, 263-278.

Chen J., Hong H., \& Stein, J.C. (2001). Forecasting crashes, Trading volume, past returns, and conditional skewness in stock prices. Journal of Financial Economics, 61 (3), 345-381.

Cheng, Q., \& Lo, K. (2006). Insider trading and voluntary disclosures. Journal of Accounting Research, 44(5), 815-848.

Choudhary, P., Koester, A., \& Pawlewicz, R. (2015). Do auditor-provided tax services affect estimation error in income tax expense?. Working paper, Georgetown University, and George Mason University.

Cohen, D., Dey, A., and Lys, T.Z. (2008). Real and accrual-based earnings management in the preand post-Sarbanes-Oxley Periods. The Accounting Review, 83(3), 757-787.

Cohen, L.J., Cornett, M.M., Marcus, A.J., \& Tehranian, H. (2014). Bank earnings management and tail risk during the financial crisis. Journal of Money, Credit and Banking, 46(1), 171-197.

Conrad, J., Dittmar, R.F., \& Ghysels, E. (2013). Ex ante skewness and expected stock returns. Journal of Finance 68(1), 85-124.

Crawford, S., Huang, Y., Li, N., and Yang, Z. (2016). Customer concentration and public disclosure: Evidence from management earnings forecasts. Working paper, university of Houston, and University of Texas.

DeFond, M.L., Hung, M., \& Li, S. (2015). Does Mandatory IFRS adoption affect crash risk? The Accounting Review, 90(1), 265-299.

DeFranco, G., Kothari, S. P., Verdi, R. S., 2011. The benefits of financial statement comparability. Journal of Accounting Research 49(4), 895-931.

Demerjian, P. R., B. Lev, M. F. Lewis, and S. E. McVay. (2013). Managerial ability and earnings quality. The Accounting Review 88 (2), 463-498.

Dimson, E. (1979). Risk measurement when shares are subject to infrequent trading. Journal of Financial Economics, 7(2), 197-226.

Donelson, D.C., McInnis, J.M. \& Mergenthaler, R.D. (2012). Rules-based accounting standards and litigation. The Accounting Review, 87(4), 1247-1279.

Doyle, J., Ge, W., McVay, S. (2007a). Accruals quality and internal control over financial reporting. The Accounting Review 82, 1141-1170.

Doyle, J., Ge, W., McVay, S. (2007b). Determinants of weakness in internal control over financial reporting. Journal of Accounting and Economics 44, 193-223.

Dyckman, T.R., \& Zeff, S.A. (2014). Some methodological deficiencies in empirical research articles in Accounting. Accounting Horizons, 28(3), 695-712. 
Ertugrul, M., Lei, J., qiu, J., \& wan, C. (2016). Annual Report readability, tone ambiguity, and the cost of borrowing. Journal of Financial and Quantitative Analysis (Forthcoming).

Faccio, M. (2006). Politically connected firms. The American Economic Review, 96, 369-386.

Farber, D.B. (2005). Restoring trust after fraud: Does corporate governance matter?. The Accounting Review, 80(2), 539-561.

Feng, M., Li, C., McVay, S. (2009). Internal control and management guidance. Journal of Accounting and Economics 48, 190-209.

Fisman, R. (2001). Estimating the value of political connections. The American Economic Review, 91, 1095-1102.

Francis B, Hasan I, \& Li L. (2014). Firms' real earnings management and subsequent stock price crash risk. Review of Quantitative Finance \& Accounting, Forthcoming.

Francis, J.R., Pinnuck, M.L., \& Watanabe, O. (2014) Auditor style and financial statement comparability. The Accounting Review, 89(2), 605-633.

French, K.R., Schwert, G.W., \& Stambaugh, R.F. (1987). Expected stock returns and volatility. Journal of Financial Economics 19, 3-29.

Gelb, D. S., \& Strawser, J. A. (2001). Corporate social responsibility and financial disclosures: an alternative explanation for increased disclosure. Journal of Business Ethics, 33(1), 1-13.

Goel, A.M., and Thakor, A.V. (2008). Overconfidence, CEO selection and corporate governance. Journal of Finance, 63(6), 2737-2784.

Gunny, K. A. (2010). The relation between earnings management using real activities manipulation and future performance: Evidence from meeting earnings benchmarks. Contemporary Accounting Research, 27(3), 855-888.

Gunny, K. A., \& Zhang, T. C. (2014). Do managers use meeting analyst forecasts to signal private information? Evidence from patent citations. Journal of Business Finance \& Accounting, 41(7-8), 950-973.

Habib, A., \& Hasan, M. (2016). Auditor-provided tax services and stock price crash risk. Accounting \& Business Research, 46(1), 51-82.

Hackenbrack, K.E., Jenkins, N.T., \& Pevzner, M. (2014). Relevant but delayed information in negotiated audit fees. Auditing: A Journal of Practice \& Theory, 33(4), 95-117.

He, G. (2015). The effect of CEO inside debt holdings on financial reporting quality. Review of Accounting Studies, 20, 501-536.

Hong, H., \& Stein, J. (2003). Differences of opinion, short-sales constraints, and market crashes. Review of Financial Studies 16, 487-525.

Huang, W., F. Jiang, Z. Liu, and M. Zhang. (2011). Agency cost, top executives' overconfidence, and investment-cash flow sensitivity-Evidence from listed companies in China. Pacific-Basin Finance Journal 19 (3):261-277.

Hui, K.W., Klasa, S., \& Yeung, P.E. (2012). Corporate suppliers and customers and accounting conservatism. Journal of Accounting and Economics 53(1\&2), 115-135.

Hutton A.P, Marcus A.J, and Tehranian H. (2009). Opaque financial reports, R2, and crash risk. Journal of Financial Economics, 94 (1), 67-86.

Jiang, J., Petroni, K., \& Wang, I. (2010). CFOs and CEOs: who have the most influence on earnings management? Journal of Financial Economics 96, 513-526

Jiang, H. \& Habib, A. (2012). Split share reform and earnings management: evidence from China. Advances in International Accounting, 28(1), 120-127.

Jin, L., \& Myers, S. C. (2006). $\mathrm{R}^{2}$ around the World: New theory and new tests. Journal of Financial Economics 79(2), 257-292.

Kraus, A. \& Litzenberger, R. (1976). Skewness preference and the valuation of risk assets. Journal of Finance 31, 1085-1100.

Kraus, A. \& Litzenberger, R. (1983). On the distributional conditions for a consumption oriented three moment CAPM, Journal of Finance 38, 1381-1391. 
Kim, Jeong-Bon, Li, Y., \& Zhang, L. (2011a). CFOs versus CEOs: Equity incentives and crashes. Journal of Financial Economics, 101(3), 713-730.

Kim, Jeong-Bon, Li, Y., \& Zhang, L. (2011b). Corporate tax avoidance and stock price crash risk: Firmlevel analysis. Journal of Financial Economics, 100(3), 639-662.

Kim, Jeong-Bon, \& Zhang, L. (2014). Financial reporting opacity and expected crash risk: Evidence from implied volatility smirks. Contemporary Accounting Research, 31(3), 851-875.

Kim, Jeong-Bon, \& Zhang L. (2015). Accounting conservatism and stock price crash risk: Firm-level evidence. Contemporary Accounting Research, Forthcoming.

Kim, Jeong-Bon, Wang, Z., \& Zhang, L. (2016). CEO overconfidence and stock price crash risk. Contemporary Accounting Research, Forthcoming.

Kim, Jeong-Bon, Li, L., Lu, L.Y., \& Yu, Y. (2016). Financial statement comparability and expected crash risk. Journal of Accounting \& Economics, Forthcoming.

Kim, Y., Li, H., \& Li, S. (2014). Corporate social responsibility and stock price crash risk. Journal of Banking \& Finance 43, 1-13.

Kim, Y., Park, M.S., and Wier, B. (2012). Is earnings quality associated with corporate social responsibility? The Accounting Review, 87(3), 761-796.

Kothari SP., Shu S., and Wysocki PD. (2009). Do managers withhold bad news? Journal of Accounting Research 47 (1), 241-276.

Krishnan, G. V. (2003). Does Big 6 auditor industry expertise constrain earnings management? Accounting Horizons, 17(Supplement), 1-16.

Kubick, T.R., \& Lockhart, B.G. (2016). Proximity to the SEC and stock price crash risk. Financial Management (Summer), 341-367.

Lanis, R., \& Richardson, G. (2012). Corporate social responsibility and tax aggressiveness: An empirical analysis. Journal of Accounting and Public Policy, 31(1), 86-108.

Larcker, D. F., Richardson, S. A., \& Tuna, I. (2007). Corporate governance, accounting outcomes, and organizational performance. Accounting Review, 82(4), 963-1008.

Lee, W. \& Wang, L. (2016). Do political connections affect stock price crash risk? Firm-level evidence from China. Review of Quantitative Finance and Accounting, 1-34.

Li, W., \& Cai, G. (2016). Religion and stock price crash risk: Evidence from China. China Journal of Accounting Research (Forthcoming).

Li, X., \& Chan, K.C. (2016). Communist party control and stock price crash risk: Evidence from China. Economics Letters, 141, 5-7.

Lin, Y., S.. Hu, \& M. Chen. (2005). Managerial optimism and corporate investment: Some empirical evidence from Taiwan. Pacific-Basin Finance Journal 13 (5):523-546.

Malmendier, U., \& G. Tate. (2005). CEO overconfidence and corporate investment. The Journal of Finance 60 (6):2661-2700.

McVay, S. (2006). Earnings management using classification shifting: an examination of core earnings and special items. The Accounting Review 81, 501-531.

Ministry of Finance (MOF). (2008). The Basic Standard of Enterprise Internal Control.

Ministry of Finance (MOF). (2010). The Internal Control Guidelines, The Internal Control Audit Guidelines.

Mitra, S., \& Cready, W. M. (2005). Institutional stock ownership, accrual management, and information environment. Journal of Accounting, Auditing \& Finance, 20(3), 257-286.

Piotroski, J. D., Wong, T. J., \& Zhang, T. (2015). Political incentives to suppress negative information: Evidence from Chinese listed firms. Journal of Accounting Research, 53(2), 405459.

Raman, K. \& Shahrur, h. (2008). Relationship-specific investments and earnings management: Evidence on corporate suppliers and customers. The Accounting Review, 83(4), 1041-1081.

Robin, A., \& Zhang, H. (2015). Do industry-specialist auditors influence stock price crash risk?. Auditing: A Journal of Practice and Theory, 34(1), 47-79. 
Rubinstein, M. E. (1973). The fundamental theorem of parameter-preference security valuation, Journal of Financial and Quantitative Analysis 8, 61-69.

Seavey, S.E., Imhof, M., \& Watanabe, O.V. (2016). Proprietary costs of competition and financial statement comparability. Working paper, University of Nebraska, Wichita State University,, and Iowa State University.

Schwert, W.G. (1990). Stock volatility and the crash of '87. Review of Financial Studies, 3(1), 77-102.

Securities and Exchange Commission (SEC). (1998). A Plain English Handbook: How to create clear SEC disclosure documents. Washington, DC: U.S. Securities and Exchange Commission.

Song, L., Du, C., \& Wu, J. (2016). Bank accounting disclosure, information content in stock prices and stock crash risk: Global evidence. Pacific Accounting Review (Forthcoming).

Srinivasan, S. (2005). Consequences of financial reporting failure for outside directors: Evidence from accounting restatements and audit committee members. Journal of Accounting Research, 43(2), 291-334.

Sunder, S. (2010). On the Accounting Train: From Crisis to Crisis in Eighty Years. In Presentation Slides: Available at http://www.som.yale.edu/faculty/Sunder/research.html.

Yuan, R., Sun, J., \& Cao, F. (2016). Directors' and officers' liability insurance and stock price crash risk. Journal of Corporate Financei, 37, 173-192.

Velury, U., \& Jenkins, D. S. (2006). Institutional ownership and the quality of earnings. Journal of Business Research, 59(9), 1043-1051.

Watts, R. L. (2003a). Conservatism in accounting part I: Explanations and implications. Accounting Horizons 17 (3), 207-221.

Watts, R. L. (2003b). Conservatism in accounting part II: Evidence and research opportunities. Accounting Horizons 17 (4), 287-301.

Wu, C.W.M. (2013). CEO turnover and stock price crash. DBA dissertation, Hong Kong Polytechnic University.

Xie, B., Davidson III, W.N. and DaDalt, P.J. (2003). Earnings management and corporate governance: The roles of the board and the audit committee. Journal of Corporate Finance, 9, 295-316.

Xu, N., Chan, K. C., Jiang, X., \& Yi, Z. (2013). Do star analysts know more firm-specific information? Evidence from China. Journal of Banking \& Finance, 37(1), 89-102.

$\mathrm{Xu}, \mathrm{N}, \mathrm{Li}, \mathrm{X}$., Yuan, Q. \& Chan, K. C. (2014). Excess perks and stock price crash risk: Evidence from China. Journal of Corporate Finance, 25, 419-434.

Xu, N., Jiang, X., Chan, K. C., \& Yi, Z. (2013). Analyst coverage, optimism, and stock price crash risk: Evidence from China. Pacific-Basin Finance Journal, 25, 217-239.

Zhang, M., Xie, L. \& Xu, H. (2016). Corporate philanthropy and stock price crash risk: Evidence from China. Journal of Business Ethics (Forthcoming).

Zhu, W. (2016). Accruals and price crashes. Review of Accounting Studies, 21, 349-399. 
TABLE1: Determinants and consequences of stock price crash risk

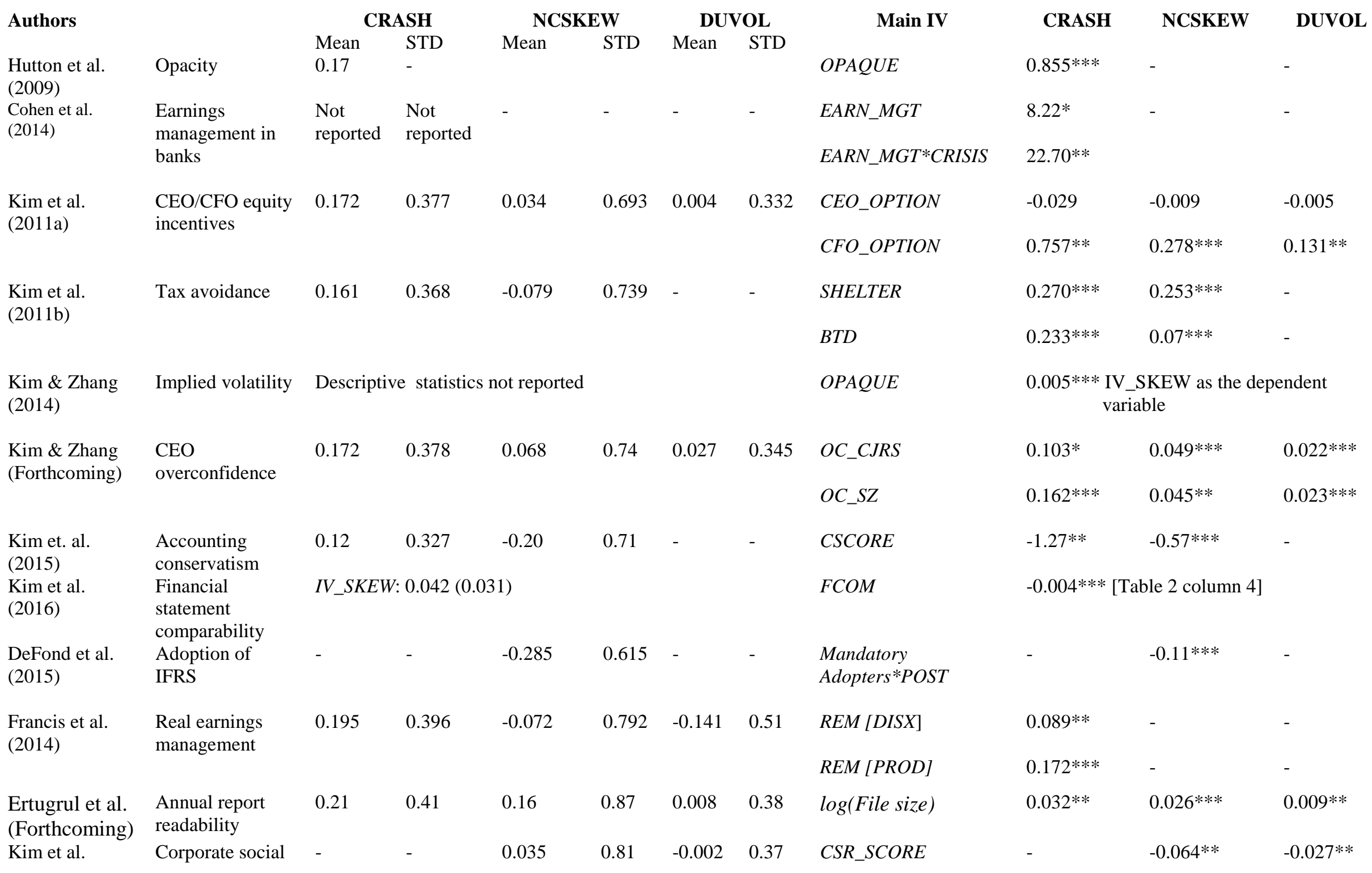




\begin{tabular}{|c|c|c|c|c|c|c|c|c|c|c|c|}
\hline$(2014)$ & responsibility & & & & & & & & & & \\
\hline $\begin{array}{l}\text { Robin \& Zhang } \\
\text { (2014) }\end{array}$ & $\begin{array}{l}\text { Auditor industry } \\
\text { specialization }\end{array}$ & 0.19 & 0.39 & -0.10 & 0.76 & -0.05 & 0.35 & SPECIALIST* & $-0.07 * * *$ & $-0.03 * * *$ & $-0.012 * * *$ \\
\hline $\begin{array}{l}\text { Habib \& Hasan } \\
(2016)\end{array}$ & $\begin{array}{l}\text { Auditor-provided } \\
\text { tax services }\end{array}$ & - & - & -0.07 & 1.17 & -0.37 & 0.91 & FEERATIO & - & $-0.017 * *$ & $-0.014 * * *$ \\
\hline $\begin{array}{l}\text { Callen and } \\
\text { Fang (2013) }\end{array}$ & $\begin{array}{l}\text { Institutional } \\
\text { investors }\end{array}$ & -0.46 & 1.67 & -0.07 & 1.24 & -0.15 & 0.56 & StdI $* 100$ & $0.30 * * *$ & $0.23 * * *$ & $0.14 * * *$ \\
\hline & & & & & & & & $D E D$ & $-0.50 * * *$ & $-0.37 * * *$ & $-0.17 * * *$ \\
\hline & & & & & & & & $T R A$ & $1.09 * * *$ & $1.14 * * *$ & $0.47 * * *$ \\
\hline $\begin{array}{l}\text { Callen \& Fang } \\
\text { (2015) }\end{array}$ & Short interest & -0.43 & 1.68 & -0.14 & 1.59 & -0.17 & 0.66 & $S I R$ & $0.64 * *$ & $0.70 * * *$ & $0.31 * * *$ \\
\hline An \& Zhang & Institutional & -0.09 & 0.70 & -0.17 & 0.94 & -0.10 & 0.41 & $I O$ & $0.054 * *$ & $0.13 * * *$ & $0.06 * * *$ \\
\hline$(2013)$ & ownership & & & & & & & $I O \_D E D$ & $-0.19 * * *$ & $-0.26 * * *$ & $-0.10 * * *$ \\
\hline & & & & & & & & IO_TRA & $0.39 * * *$ & $0.66 * * *$ & $0.30 * * *$ \\
\hline $\begin{array}{l}\text { Lee \& Wang } \\
\text { (2016) }\end{array}$ & $\begin{array}{l}\text { Political } \\
\text { connections }\end{array}$ & & & -0.173 & 0.676 & -0.06 & 0.242 & PCD*IDENTITY & - & $0.407 * * *$ & $0.165 * * *$ \\
\hline $\begin{array}{l}\text { Andreou et al. } \\
(2016)\end{array}$ & $\begin{array}{l}\text { Corporate } \\
\text { governance }\end{array}$ & - & - & 0.101 & 0.811 & -0.00 & 0.364 & $\begin{array}{l}\text { Nine PCF scores from } \\
21 \text { individual CG } \\
\text { variables }\end{array}$ & - & $\begin{array}{l}\text { Too many } \\
\text { tabled }\end{array}$ & bles to be \\
\hline $\begin{array}{l}\text { An \& Zhang } \\
(2013)\end{array}$ & $\begin{array}{l}\text { Institutional } \\
\text { investor }\end{array}$ & -0.09 & 0.70 & -0.17 & 0.94 & -0.10 & 0.41 & $I O$ & $0.05^{* *}$ & $0.13 * * *$ & $0.06 * * *$ \\
\hline & & & & & & & & $D E D$ & $-0.19 * * *$ & $-0.26 * * *$ & $-0.01 * * *$ \\
\hline Xu et al. (2014) & Excess perks & - & - & -0.365 & 0.630 & -0.273 & 0.457 & ExcessPerk & - & $0.247 * * *$ & $0.136^{* * *}$ \\
\hline Aman (2013) & Media Coverage & - & 0.706 & - & - & - & - & MEDIA & $0.26 * * *$ & - & - \\
\hline $\begin{array}{l}\mathrm{Li} \text { and Chan } \\
(2016)\end{array}$ & $\begin{array}{l}\text { Communist Party } \\
\text { Control }\end{array}$ & - & - & - & - & - & - & PARTY_DIR & - & $-0.061 * *$ & - \\
\hline Xu et al. (2013) & Analyst & 0.09 & 0.29 & -0.14 & 0.66 & -0.1 & 0.48 & Analyst & $0.019 * * *$ & $0.008 * *$ & $0.005 * *$ \\
\hline & coverage, & & & & & & & Analyst_OPT & $0.024 * * *$ & $0.011 * *$ & $0.007 * *$ \\
\hline & forecast & & & & & & & Analyst_IB & $0.02 * * *$ & $0.009 * * *$ & $0.007 * * *$ \\
\hline & $\begin{array}{l}\text { optimism and } \\
\text { conflict of } \\
\text { interest }\end{array}$ & & & & & & & Analyst_Affiliated & $0.023 * * *$ & $0.009 * * *$ & $0.006 * * *$ \\
\hline $\begin{array}{l}\text { Yuan et al. } \\
\text { (2016) }\end{array}$ & $\begin{array}{l}\text { D\&O liability } \\
\text { insurance }\end{array}$ & - & - & -0.215 & 0.793 & -0.251 & 0.733 & $D \& O$ & - & $-0.137 * * *$ & $-0.113 * * *$ \\
\hline He (2015) & CEO inside debt & - & - & - & - & - & - & InsiDebt & $-0.1458 * *$ & - & - \\
\hline $\begin{array}{l}\text { Chang et al. } \\
\text { (Forthcoming) }\end{array}$ & Stock liquidity & 0.19 & 0.39 & 0.008 & 0.76 & - & - & $L I Q$ & $0.216^{* * *}$ & $0.057 * * *$ & - \\
\hline Piotroski et al. & Political & - & - & -0.650 & 0.674 & - & - & Political & - & $-0.253 * * *$ & - \\
\hline
\end{tabular}




\begin{tabular}{|c|c|c|c|c|c|c|c|c|c|c|c|}
\hline $\begin{array}{l}\text { Kubick \& } \\
\text { Lockhart } \\
\text { (2016) }\end{array}$ & $\begin{array}{l}\text { Proximity to } \\
\text { SEC }\end{array}$ & 0.19 & 0.39 & 0.008 & 0.67 & -0.011 & 0.32 & SEC Distance & $0.05 * *$ & $0.03^{* * *}$ & $0.018 * * *$ \\
\hline $\begin{array}{l}\text { Callen \& Fang } \\
\text { (2016) }\end{array}$ & Religion & -0.66 & 1.70 & -0.21 & 0.59 & -0.23 & 1.15 & $R E L$ & $-0.13 * *$ & $-0.077 * *$ & $-0.13 * *$ \\
\hline $\begin{array}{l}\mathrm{Li} \& \text { Cai } \\
\text { (Forthcoming) }\end{array}$ & Religion & - & - & -0.19 & 0.61 & -0.18 & 0.45 & RELIGION & - & $-0.81 * * *$ & $-0.69 * * *$ \\
\hline $\begin{array}{l}\text { Zhang et al. } \\
\text { (2016) }\end{array}$ & Donations & - & - & -0.24 & 0.82 & -0.17 & 0.69 & Donations & - & $-0.0024 * *$ & $-0.0026 * * *$ \\
\hline & & & & & & & & Donations*SOE & - & $0.0051 * *$ & $0.0058 * * *$ \\
\hline
\end{tabular}

Note: In the following we define those variables which have been used infrequently in the surveyed studies

- Tax fee ratio (FEERATIO): tax fees received by audit firms as a proportion of audit fees.

- Incentive ratio $(\boldsymbol{O N E P C T})$ : The dollar change in the value of a manager's option holdings that would come from a one-percentage-point increase in the company stock price.

- Institutional ownership stability (INSTOWN_Stable): Average standard deviation of institutional shareholding proportions across all investors in a firm over a 5-year period including sample year and the 4 years preceding it (i.e., 20 quarters).

- Dedicated institutional investor $(\boldsymbol{D E} \boldsymbol{E})$ is the percentage of shares outstanding held by dedicated institutions at the end of the year.

- Transient institutional investor (TRA) is the percentage of shares outstanding held by transient institutions at the end of the year.

- Short interest (SIR): The number of shares sold short divided by total shares outstanding from the last month of fiscal year $t$, with a range from 0 to 1. Compustat Supplemental Short Interest File provides the available data to calculate short interest.

- CEO overconfidence $\left(\boldsymbol{O C} \_\boldsymbol{C J R S}\right)$ : Dummy variable coded 1 if the CEO holds options at least twice during the sample period that are more than 100 percent in the money, and zero otherwise.

- CEO overconfidence $\left(\boldsymbol{O C} \_S Z\right)$ : It takes the value of one if the firm meets the requirements of at least three of the following five criteria and zero otherwise: (i) Excess investment is in the top quartile within industry years; (ii) net acquisitions from the statement of cash flows are in the top quartile within industry-years; (iii) the debt-to equity ratio is in the top quartile within industry-years; (iv) either convertible debt or preferred stock is greater than zero; and (v) the dividend yield is zero.

- Religion (RELIGION) (Li \& Cai, Forthcoming): The distance between the registered address of the listed company and the site of religious activity.

- Religion (REL) (Callen \& Fang 2015): Religiosity data from the Association of Religion Data Archives (ARDA). Once every decade, the Glenmary Research Center collects data from surveys on religious affiliation in the United States (1971, 1980, 1990, and 2000). Based on the survey results, the center reports county-level data on the number of churches and the number of total adherents by religious affiliation.

- Political connection (PCON): Number of politically connected directors on the board divided by the total number of directors. A board member as a politically connected director if he or she formerly (currently) served (serves) in one of the following posts: (1) government 
official, (2) member of the Chinese People's Congress (CPC), (3) member of the Chinese People's Political Consultative Conference (CPPCC), or (4) military official.

- Media coverage (MEDIA): Iinformation from Nikkei Telecom 21 on the number of citations over one year in four commercial newspapers, The Nikkei, the Nikkei Business Daily, the Nikkei Finance Journal, and the Nikkei Marketing Journal.

- Annual report readability $(\boldsymbol{l o g}(\boldsymbol{F i l e}$ size $)$ : The natural logarithm of the file size in megabytes of the SEC EDGAR "complete submission text file" for the 10-K filing.

- Excess perks (ExcessPerk): Actual perk consumption minus expected perk consumption whereby the latter is derived by regressing perks consumption (scaled by revenue) on natural log of total compensation for all firm employees, firm size, and the natural log of total income per capita of the region in which the firm is located.

- Communist party control (CPC): A dummy variable coded 1 if any members of the CPC committee are also directors, supervisors, or senior executives; otherwise it is zero.

- Inside debt (InsiDebt): A dummy variable, which takes value of 1 if CEO relative leverage exceeds 1 and 0 otherwise (See Appendix 2 of the paper for the detailed calculation of CEO leverage).

- Proximity to the SEC (SEC distance): The distance between the firm's headquarters and the closest SEC regional or national office. SEC national office in Washington DC and regional offices in New York City, Miami, Chicago, Denver, and Los Angeles.

- Stock liquidity $(\boldsymbol{L I} Q)$ : -100 times relative effective spread, which is the ratio of the difference between the trade price and the midpoint of the bid-ask quote over the trade price.

- Political incentives (Political and Post-Political): An indicator variable equal to one if the firm-year relates to a specific political event (i.e., National Congress or Provincial-Level Political Promotion), zero otherwise. An indicator variable equal to one in the year immediately following the political event, zero otherwise. 
TABLE2: Determinants of stock price crash risk

\begin{tabular}{|c|c|c|c|c|}
\hline Authors & Research question & Sample & $\begin{array}{l}\text { Sample period } \\
\text { justification }\end{array}$ & Findings \\
\hline \multicolumn{5}{|c|}{ Financial reporting quality, bad news hoarding and crash risk } \\
\hline $\begin{array}{l}\text { Hutton et al. } \\
(2009)\end{array}$ & $\begin{array}{l}\text { To examine the } \\
\text { effect of } \\
\text { transparency of } \\
\text { financial statement } \\
\text { on crash risk. }\end{array}$ & $\begin{array}{l}1991-2005 \\
\text { sample } \\
\text { period with a } \\
\text { final sample } \\
\text { of } 40,882 \\
\text { firm-years. }\end{array}$ & $\begin{array}{l}\text { Direct method CF } \\
\text { data because first } \\
\text { available in } 1987 . \\
\text { Sample periods begin } \\
\text { in } 1991 \text { as three } \\
\text { annual lags of cash } \\
\text { flow data is needed } \\
\text { for estimating } \\
\text { accruals. }\end{array}$ & $\begin{array}{l}\text { Firms with opaque financial statements } \\
\text { are more prone to stock price crashes. } \\
\text { However, this relation more is } \\
\text { pronounced before the passage of the } \\
\text { Sarbanes-Oxley Act. }\end{array}$ \\
\hline $\begin{array}{l}\text { Francis et al. } \\
(2014)\end{array}$ & $\begin{array}{l}\text { To examine the } \\
\text { impact of real } \\
\text { earnings } \\
\text { management on } \\
\text { future stock price } \\
\text { crash. }\end{array}$ & $\begin{array}{l}\text { 1989-2009 } \\
\text { sample } \\
\text { period with } \\
44,731 \text { firm- } \\
\text { year } \\
\text { observations }\end{array}$ & $\begin{array}{l}\text { No justification for } \\
\text { sample period. }\end{array}$ & $\begin{array}{l}\text { Firms that deviate in real operations } \\
\text { from industry norms are positively } \\
\text { associated with future crash risk. }\end{array}$ \\
\hline $\begin{array}{l}\text { Kim and Zhang } \\
\text { (2015) }\end{array}$ & $\begin{array}{l}\text { To investigate } \\
\text { whether conditional } \\
\text { conservatism in } \\
\text { financial reporting } \\
\text { affects price } \\
\text { crashes. }\end{array}$ & $\begin{array}{l}1962-2007 \\
\text { sample } \\
\text { period with } \\
114,548 \text { firm- } \\
\text { year } \\
\text { observations }\end{array}$ & $\begin{array}{l}\text { No justification for } \\
\text { the start of sample } \\
\text { period in } 1962 .\end{array}$ & $\begin{array}{l}\text { Conditional conservatism reduces the } \\
\text { likelihood of a firm experiencing future } \\
\text { price crashes. Furthermore, changes in } \\
\text { the degree of conditional conservatism } \\
\text { are also negatively associated with } \\
\text { changes in future crash risk. }\end{array}$ \\
\hline $\begin{array}{l}\text { Kim et al. } \\
(2011 b)\end{array}$ & $\begin{array}{l}\text { To examine the } \\
\text { association between } \\
\text { tax avoidance and } \\
\text { crash risk }\end{array}$ & $\begin{array}{l}1995-2008 \\
\text { sample } \\
\text { period with } \\
87,162 \text { firm- } \\
\text { year } \\
\text { observations }\end{array}$ & $\begin{array}{l}\text { To ensure the } \\
\text { consistent } \\
\text { measurement of tax } \\
\text { avoidance variables, } \\
\text { following the } \\
\text { enactment of FAS } \\
109 \text {, Accounting for } \\
\text { Income Taxes, the } \\
\text { authors start sample }\end{array}$ & $\begin{array}{l}\text { Various forms of tax avoidance increase } \\
\text { crash risk. }\end{array}$ \\
\hline
\end{tabular}

\section{Economic significance of the coefficient of interest}

Financial reporting opacity accounts for $15.8 \%$ of the variation in crash risk.

One standard deviation change around the mean of 3 years' absolute value of deviation in real operations increases crash likelihood by $0.94 \%$

A one standard deviation increase in the Basu (1997) coefficient reduces crash probability by $46.4 \%$.

Logistic regression revels that the marginal effect of the tax avoidance measure on crash risk is $3.6 \%$ for SHELTER, $4.1 \%$ for LRETR, and $3.1 \%$ for BTDFACTOR. Economic significance for tax avoidance variable for two 
period in 1995.

Zhu (2016)
Investigates the relation between accruals and price crashes.

\author{
A total of None provided \\ 108,184 firm- \\ year \\ observations \\ between \\ 1965 and \\ 2013.
}

\section{Kim et al}

(2014)

Ertrugrul et al.

(Forthcoming)

Examines the
effects of annual
report readability
and tone ambiguity
on crash risk and

on crash risk and

borrowing costs

\section{To examine the effect of CSR}

disclosures on crash risk

1995-2009

sample

period and

12,978 firm-

year

observations

A total of None provided
32,207 firm-
year
observations
and 1995-
2013 sample
period

Kubick \&

Examines whether

Lockhart (2016) proximity to SEC

('geography of crash risk') impacts crash risk
A total of 18,081 firmyear

observations from 1996 to 2012

\section{Availability of CSR} data from 1994 from

KLD database and use of one year lagged value allow the authors to begin the sample period from 1995 .

YES. “...sample begins in 1996 [to] obtain historical zip codes from firm $10-\mathrm{K}$ filings..."
A strong positive association between total accruals and price crashes is found which is consistent with the hidden bad news explanation. With respect to the components of accruals, Zhu (2016) finds that less (more) reliable accrual components are significantly positively (not significantly) associated with price crashes,

Firms with better CSR scores are less prone to crash risk. The role of CSR in reducing stock price crash risk is particularly important when internal monitoring by the boards or external monitoring by institutional investors is weak.

Firms with larger reports and a higher proportion of uncertain and weak expressions experience greater crash risk supporting the argument that readability of a firm's financial disclosures are related to managerial information hoarding.

Firms further away from SEC office are more likely to experience crash. This effect is more pronounced for firms with larger $10-\mathrm{K}$ file sizes. This is consistent with managerial influence over annual report disclosures with an intent to obfuscate bad news when there is greater distance between managers and the SEC. other crash risk measures is not reported.

The probability of observing price over the next year increases from $12.88 \%$ for the lowest decile of the current year's accruals to

$17.27 \%$ for the highest decile.

On average, an increase of one standard deviation in CSR SCORE is associated with a decrease of 0.052 in NCSKEW in year t. DUVOL, too, is economically significant.

A one SD increase in readability score would lead to an $18.2 \%$ increase in the average value of NCskew

A change from $1^{\text {st }}$ to the $3^{\text {rd }}$ quartile of the distance from SEC variable increases crash risk by $0.75 \%$. 


\section{External monitoring and crash risk}

\begin{tabular}{|c|c|c|c|}
\hline $\begin{array}{l}\text { Robin and } \\
\text { Zhang (2014) }\end{array}$ & $\begin{array}{l}\text { To examine } \\
\text { whether the } \\
\text { industry-specialist } \\
\text { auditors influence } \\
\text { crash risk }\end{array}$ & $\begin{array}{l}\text { 1990-2009 } \\
\text { sample } \\
\text { period with } \\
\text { 58,365 firm- } \\
\text { year } \\
\text { observations. }\end{array}$ & $\begin{array}{l}\text { No justification for } \\
\text { the sample period. }\end{array}$ \\
\hline $\begin{array}{l}\text { Habib \& Hasan } \\
\text { (2016) }\end{array}$ & $\begin{array}{l}\text { To investigate the } \\
\text { association between } \\
\text { NATS and crash } \\
\text { risk. }\end{array}$ & $\begin{array}{l}2002-2012 \\
\text { sample } \\
\text { period with } \\
21,950 \text { firm- } \\
\text { year } \\
\text { observations }\end{array}$ & $\begin{array}{l}\text { Sample period begins } \\
\text { from } 2002 \text { as } \\
\text { Congress ratified } \\
\text { SOX in this year. }\end{array}$ \\
\hline $\begin{array}{l}\text { Callen and Fang } \\
\text { (2013) }\end{array}$ & $\begin{array}{l}\text { To examine the } \\
\text { association between } \\
\text { institutional } \\
\text { investor stability } \\
\text { and stock price } \\
\text { crash risk. }\end{array}$ & $\begin{array}{l}\text { 1981-2008 } \\
\text { sample } \\
\text { period with } \\
61,705 \text { firm- } \\
\text { year } \\
\text { observations. }\end{array}$ & $\begin{array}{l}\text { No justification for } \\
\text { the sample period. }\end{array}$ \\
\hline $\begin{array}{l}\text { An and Zhang } \\
\text { (2013) }\end{array}$ & $\begin{array}{l}\text { To examine the } \\
\text { impact of } \\
\text { institutional } \\
\text { investors on stock } \\
\text { price synchronicity } \\
\text { and crash risk }\end{array}$ & $\begin{array}{l}\text { From } 1987 \\
\text { through } 2010 \\
\text { sample } \\
\text { period with } \\
79,932 \text { firm- } \\
\text { year } \\
\text { observations }\end{array}$ & $\begin{array}{l}\text { Sample period begins } \\
\text { from } 1987 \text { as the } \\
\text { historical SIC data is } \\
\text { missing in Compustat } \\
\text { before } 1987 .\end{array}$ \\
\hline
\end{tabular}

Information intermediary and corporate governance roles of auditor industry specialization reduce crash risk. Moreover, industry-specialist auditors moderate the effects of opacity, accounting conservatism, and tax avoidance on crash risk.

NATS attenuate crash risk by No
constraining both tax expenses
management and tax avoidance.
Further, NATS reduce crash risk for
firms following innovative business
strategies. Empirical findings, therefore,
support knowledge spillover benefits.

Institutional investor stability is negatively associated with one-yearahead stock price crash risk. Moreover, this relationship varies depending on whether institutional owners are public pension funds or bank trusts, investment companies and independent investment advisors.

One year ahead crash risk increase by $5.3 \%$ with a shift from the 25 th to the 75 th percentile of the distribution of standard deviation of institutional shareholding.

Monitoring by dedicated institutional investors mitigates managerial badnews hoarding, which reduces crash risk and stock price synchronicity

observations
A one-standard deviation increase of dedicated institutional ownership will lead to an $17 \%$ decrease in crash risk at the mean, while a similar increase of transient institutional investors will increase crash risk by $46 \%$ at the mean. 
Lee \& Wang (2016)

Examines the association between political connections and crash risk

A total of 4,680 firmyear observations during 2003 to 2012
Sample period begins in 2003 because the

China

Securities Regulatory Commission (CSRC) required Chinese listed firms to report the identity of the ultimate controller in the annual report from 2003

Politically connected directors accentuates crash risk in listed SOEs courtesy of appointment of local government officials as directors. In contrast, appointment of centralgovernment-affiliated directors, helps listed privately controlled firms to reduce crash risk. The presence of good quality institutions does not help to attenuate the adverse effect of political connections on crash risk for listed SEOs.

\section{Internal corporate governance mechanism and stock price crash risk}

Andreou et al. (2016)

Kim, Li, and Zhang (2011)

Kim et al (2014)
To examine the association between corporate governance systems and firm specific stock price crashes.

\begin{tabular}{|c|c|}
\hline $\begin{array}{l}\text { ine the } \\
\text { ontribution } \\
\text { yersus } \\
\text { quity } \\
\text { s for future } \\
\end{array}$ & $\begin{array}{l}3-2009 \\
\text { aple } \\
\text { iod with } \\
638 \text { firm- } \\
\text { ir } \\
\text { ervations }\end{array}$ \\
\hline $\begin{array}{l}\text { sociation between } \\
\text { EO } \\
\text { verconfidence and } \\
\text { ock price crash } \\
\text { sk }\end{array}$ & $\begin{array}{l}1993-2010 \\
\text { sample } \\
\text { period with } \\
23,925 \text { firm- } \\
\text { year } \\
\text { observations }\end{array}$ \\
\hline
\end{tabular}

No justification for the sample period.

period with 6,620 firm-

year

observations

\section{No justification for} the sample period.

No justification for the sample period.
Stock price crashes are positively associated with institutional ownership and financial reports opacity, while negatively associated with percentage of independent directors on the audit committee and auditor industry expertise and clearly defined corporate governance policy.

CFO's equity incentives are positively related to the firm's future crash risk. This association is more pronounced for CFOs and in firms operating in noncompetitive industries and those with a high level of financial leverage.

Overconfident CEOs are associated with higher stock price crash risk, an association which is pronounced if the $\mathrm{CEO}$ is more dominant among the top management team.
Economic significance not explained
A change in the corporate governance measures from the 25 th to 75 th percentile explains from $23.01 \%$ to $29.48 \%$ of the standard deviation of the crash risk.

No

Firms with overconfident CEOs are associated with $1.2 \%$ to $3.6 \%$ more crash risk compared to firms without overconfident CEOs. 
To investigate the association between
A sample of

Chinese

firms listed

on the

Shanghai and

Shenzhen

stock

exchanges

from 2007

to 2012

A total of 5,685 firm-

year

observations from 2006 to 2011
Chen, Chan,

Dong and

Zhang (2016) internal control quality and stock price crash risk

\section{$\mathrm{He}(2015)$}

\section{Examines the effects of CEO inside debt on financial reporting quality including crash risk}

The internal control index covers Chinese

listed firms from 2007 to 2012 .

\section{Starting from \\ December 15, 2006 the SEC required \\ public firms to \\ disclose detailed \\ information about the computation and \\ value of executive \\ pension benefits and \\ deferred \\ compensation.}

\section{Prediction of crash risk}

\section{Chen et al.}

(2001)

$\begin{array}{ll}\text { To forecast } & \begin{array}{l}1962-1998 \\ \text { skewness in the }\end{array} \\ \text { daily returns } & \text { period with } \\ \text { to individual stocks } & \begin{array}{l}51,426 \text { firm- } \\ \text { year } \\ \text { observations. }\end{array}\end{array}$

Sample period begins in 1962 as trading volume data is available from this period.
Internal control is negatively associated with price crash, and this negative relation is more pronounced in firms with weak governance (i.e. non-Big 4 auditors, located in provinces with low market development, and less conservative accounting) and with poor ability to mitigate impacts of extreme negative events (i.e. non-state-owned enterprises).

CEO inside debt holdings reduce firmspecific stock price crash risk.
A one SD increase in InsiDebt decreases the incidence of a stock price crash by $3.1 \%$ points, which accounts for $15.38 \%$ of the sample mean of Crash.
It is estimated that when internal control quality increases from the first to the third quartile, the crash risk proxy NCSKEW decreases by 0.034 , which is $19.73 \%$ of the median value of NCSKEW.
A two-standard-deviation shock to DTURNOVER translates into a movement of 0.06 in the NCSKEW variable. 
Callen and Fang To investigate (2015) whether short interest is associated with crash risk
40,660 firmyear observations for the years 1981 to 2011.
Short interest

information is

available from 1981

\section{Informal institutions and crash risk}

Callen \& Fang To investigate the (2015) effects of religion on crash risk

\section{Sample} observations explicitly stated, the 80,404 from 1971 to 2000 .

\section{data source, i.e.,}

\section{Glenmary Research}

Center collects data

from surveys on

religious affiliation once in a decade.

\section{3-2013 No justification sample provided}

Cai \& Li (2016) $\begin{aligned} & \text { To investigate the } \\ & \text { effects of religion }\end{aligned}$ on crash risk

period with

11,171 firm-

year

observations

A sample of There were sufficient Chinese number of firms

SOEs from that voluntarily

2003 to 2010 . disclosed their perk expenses from 2003 and beyond and it was also the first year with
One-year ahead stock price crash risk is positively associated with short interest. This positive association is more pronounced for firms with weak governance monitoring mechanisms, excessive risk taking behavior, and high information asymmetry. Firms headquartered in counties with
higher levels of religiosity exhibit lower levels of future stock price crash risk consistent with the view that religion, as a set of social norms, helps to curb badnews-hoarding activities by managers. This negative association is more pronounced for riskier firms and for firms with weaker governance mechanisms.

Companies headquartered in provinces No with more religious activities experiences less crash risk. The negative relationship manifests through religions effect on constraining earnings management and perk consumption. Finally, the negative relationship is stronger with better corporate governance and strong legal regime.

A change in the short interest from the 25th to 75th percentile explains on average $12.25 \%$ of the sample-mean across alternative measures of crash risk.

A shift from the 25th to the 75th percentiles of the distribution of religiosity reduces crash risk by 6.34\% (NCSKEW), $4.85 \%$ (DUVOL), and $3.78 \%$

(CRASH)

Motivated by the intention to enjoy No. excess perks, executives in state-owned enterprises withhold bad news for extended periods, leading to higher future stock price crash risk. 
available institutional

ownership data.

$\begin{array}{ll}\text { Aman (2013) } \quad \text { Media Coverage } & \text { A sample of } \\ & \text { Japanese } \\ & \text { companies } \\ & \text { from April } \\ & 2003 \text { to } \\ & \text { March } 2006\end{array}$

Li and Chan

Communist Party

Control

D\&O liability

insurance

(2016)

Piotroski et al.

(2013)

No.

\section{A sample of No justification \\ Chinese provided \\ SOEs from \\ 2003 to 2012 ,}

A sample of

Chinese

listed firms

from 2002 to

2012.

2002 is chosen as the beginning year of the sample period insurance appeared in that year.

A sample of No.

listed because the first $\mathrm{D} \& \mathrm{O}$

Chinese

firms over

the period

1993 to 2011.
Intensive media reports on a firm

provoke extremely large reactions in the market to corporate news.

An increase of one standard deviation in InMEDIA generates a 0.082 s.d. increase in CRASH

SHARE [1\%] and the normalized effect of InMEDIA [Others] is a 0.224 s.d. increase.

Having a CPC committee member No. serves as a director can lower a firm's crash risk.

D\&O insurance in China is negatively associated with stock price crash risk, and this effect is more pronounced in firms with lower board independence, non-Big 4 auditors, lower institutional shareholdings, and weaker investor protection.

Listed firms experience a reduction in negative stock return skewness before two visible political events including meetings of the National Congress of the Chinese Communist Party and highlevel, provincial-level political

Promotions.
No.

No. 


\section{APPENDIX: List of working papers with descriptions}

Author(s)

Chen, Khurana, \& Zheng (2014),

Amadeus \& Sadka (2015)

Kim, Wang, \& Zhang (2015)

Dang, Lee, Liu, and Zeng (2016)

Hamm, Li, \& Ng (2016)

Jeong-Bon Kim, Yeung \& Zhou (2013)

Liu (2015)

$\mathrm{Hu}$, Jeong-Bon Kim \& Zhang (2016)
Description

Cash flow opacity and stock price crash risk: Cheng et al. (2014) find that CFO opacity provides incremental explanatory power for crash risk beyond accruals-based earnings opacity. This adverse impact is less pronounced for firms with analyst cash flow forecasts, firms near financial distress, and firms with long-term issuer credit ratings. Executive compensation convexity and firm crash risk: Executive compensation convexity, measured as the sensitivity of managerial equity compensation portfolios to stock volatility, predicts firm specific crashes. A bottom-totop decile change in compensation convexity results in a $21 \%$ increase in a firm's crash risk.

Readability of 10-K Reports and stock price crash risk: Using the Fog Index as the measure of readability of annual reports, the authors find that more complex reports lead to greater crash risk. This finding implies that strategic disclosures in the form of less readable financial reports allow managers to withhold adverse information. Additional tests reveal that the positive association is stronger for firms with (persistent) negative earnings news, for firms with low litigation risk but with more CEO equity incentives, and during both the pre and post-SOX periods.

Does debt maturity affect stock price crash risk: Dang et al. (2016) find that firms with a larger proportion of shortterm debt experience lower crash risk, implying that short-maturity debt acts as a monitoring mechanism on managerial bad news hoarding behavior. The study also finds a substitutive relationship between short-maturity debt and other governance mechanisms.

Earnings guidance, bias, and stock price crash risk: Hamm et al. (2016) find that management earnings guidance (one type of voluntary disclosure) increases crash risk, and this is more pronounced for firms with higher executive stock ownership, weaker external monitoring, lower litigation risk, more upward-biased forecasts, and more opaque earnings.

Material weakness in internal control and stock price crash risk: Evidence from SOX Section 404 Disclosure: Kim et al. (2013) find that in general, firms with ICW are more prone to price crash than firms without such problem and the crash risk is greater if firms' ICW is fraud-related. More importantly, the authors find that the increase in crash risk started two years before the disclosure of adverse opinion of firms' internal control is made, but it gradually reduces after ICW disclosure and eventually disappears if remediation of internal control is undertaken by firms. Do executives have fixed effects on firm-level stock price crash risks: Liu finds that both individual CEOs and CFOs are associated with the cross-sectional variation in most of the crash risk proxies used. The CEO /CFO fixed effects were found to be related to fixed managerial ability (the portion of managerial ability attributed to each switching manager from the ability measure developed by Demerjian 2012).

Insider trading and stock price crash risk: International Evidence from a Natural Experiment: Using an international sample, Hu et al. (2013) find that the initial insider trading law enforcement leads to a significant reduction in crash risk which is more pronounced in countries with poor quality of institutional infrastructures. 
Wang (2012)

Deng, Gao, \& Kim (2016)

Luo \& Ren (not dated)

Habib \& Hasan (2016)

Hamers, Renders, and Vost (2016)

Kim, Luo, \& Xie (2016)

Dang, Faff, Luong, \& Nguyen (2016)

Not known

Chen, Kim, \& Yao (2015)

Boehme, Fotak, \& May (2016)
Overvaluation, financial opacity and crash risk: Wang (2012) finds that overvalued firms tend to use more earnings management (higher financial opacity) and they do so to conceal firm specific information from the investors resulting in greater higher crash risk than otherwise identical but non-overvalued firms.

The pathogen, scapegoat, or a miracle drug? Short selling and stock price crash risk: Employing the differencein-differences approach and a regulatory change from the SEC, as an exogenous shock, they find that the lifting of short-sale constraints reduces the stock price crash risk. The beneficial effect is stronger for firms with more severe agency problems and greater information asymmetry.

Short sale, margin purchase, and stock price crash risk: Results of difference in different tests reveal that the removal of bans on short-sale and margin-purchase is followed by a reduction in stock price crash risk over the subsequent six months in China.

Business strategy, overvalued equities, and stock price crash risk: Using a composite strategy score developed by Bentley, Omer and Sharp (2013), the authors document that firms following innovative business strategies (prospectors) are more prone to future crash risk than defenders. Further, prospectors are more prone to equity overvaluation which, in turn, increases future crash risk.

Firm life cycle and stock price crash risk: Hamers et al. (2016) document that crash risk is highest in the introduction and growth stage due probably to heterogeneity in investor beliefs and investor overoptimism. They further document that growth-stage firms without short interest are subject to greater crash risk than growth-stage firms with short interest.

Dividend payments and stock price crash risk: Dividends payments reduce crash risk because (i) firms paying dividends have better quality earnings (ii) are more likely to access external capital market and thus are subject to external monitoring, and (iii) and are constrained from overinvestment in pet projects courtesy of the more free cash flows (FCF).

National culture and stock price crash risk: Using an international sample, the authors find that firms headquartered in countries that promote strong individualism (are characterized by a high degree of uncertainty avoidance) are more (less) likely to experience stock price crash risk. The findings, therefore, suggest that individualism encourages managerial bad-news hoarding whereas uncertainty avoidance curbs such behavior.

Gender on corporate boards and crash risk: A positive relationship is found between females on boards appointed for the first time and crash. But a negative association between the presence of females on boards for a longer period and crash.

Earnings smoothing and stock price crash risk: A higher degree of earnings smoothing is associated with greater crash risk; however, this association is less pronounced for firms with more analyst following and higher institutional shareholdings. Stock price crash risk increases when earnings smoothing is accompanied by cumulative positive discretionary accruals.

Crash risk and seasoned equity offerings: The issuance of seasoned equity is associated with future stock price crash risk. The association between seasoned equity offerings and crash risk is stronger among offerings that involve the sale of secondary shares. In analyses of open market insider trading prior to crashes, the authors find that net selling by 
CEOs and CFOs is abnormally high in years succeeded by crashes relative to years not succeeded by crashes and is especially high among seasoned equity issuers that subsequently crash.

Product market threats and stock crash risk: Competitive pressure from the product market causes a firm to withhold negative information. Using fluidity as the main measure of product market threats, they find that firms facing more threats are more prone to stock crashes. This result is confirmed by an instrumental variable analysis and a difference-in-difference analysis with exogenous shock to market competition.

Firth, Wong, \& Zhou (2015)

Wang (2012)

Andreou, Cooper, Louca, \& Philip (2016)

$\mathrm{Xu}$, Jing, Chan, \& Wu (not dated)

Chen, Zhang, \& Zhang (2015)

Mamun, Balachandran, \& Duong (2016)

Bao, Fung \& Su (2015)
Corporate accessibility, private communications and stock price crash risk: stock price crash risk of accessible firms (based on their responses to outsiders' attempted communications with them) is lower than that of non-accessible firms, with the results being more pronounced when public information environment is opaque. Furthermore, accessible firms' crash risk declines less when short-selling constraints are removed, have lower market synchronicity, and have more corporate site visits made by market participants.

Does the balance sheet prevent managers from hiding bad news? Evidence from firm-specific crash risk: Using net operating assets scaled by total assets $(N O A)$ as a proxy for balance sheet bloat, Wang (2012) find a positive association between the two but during the pre-SOX regime. The relationship becomes negative in the post-SOX period. NOA's predicative power has largely dissipated since the passage of SOX.

Bank loan loss accounting treatments, credit cycles and crash risk: Conditional conservatism accounting reduces the crash risk of small banks during periods of credit contraction and boom, but that for large banks the risk of stock price crashes is not reduced by more conservative accounting, even for those with higher levels of opacity.

Analyst herding and stock price crash risk: Evidence from China: Xu et al. find that firms with disproportionately more analysts herding, have higher future stock price crash risk. The positive relation between analyst herding behavior and future stock price crash risk is more pronounced when firms have higher information asymmetry. Further, we find that analyst herding behavior is not related to positive stock price jumps, suggesting that analysts do not hold back good news for a firm.

CEO duality and stock price crash risk: Evidence from China: CEO duality increases crash risk in China. The relationship is more pronounced for firms with high information asymmetry, namely those with relatively higher R\&D expenditure, higher advertising expenditure, lower product market competition, and lower analyst coverage.

Powerful CEOs and stock price crash risk: Firms with powerful CEOs experience greater crash. The impact of earnings management, tax avoidance, $\mathrm{CFO}$ option incentives and CEO overconfidence on crash is more pronounced for firms with powerful CEOs. The takeover index, proxy for corporate governance engendered by legal environment, mitigate stock price crash for firms with non-powerful CEOs, however, has no impact for firms with founder CEOs.

Product market competition does not attenuate the positive impact of CEO power on crash.

Can shareholders be at rest after adopting clawback provisions? Evidence from stock price crash risk: Stock price crash risk increases after firms voluntarily adopt clawback provisions in managers' compensation contract. Total upward (but not downward) earnings management increases for clawback adopters, and the increase in crash risk is driven by firms with more income-increasing total earnings management after adopting clawback provisions. In addition, the positive association between clawback adoption and crash risk is more pronounced for firms with low 
institutional holdings and with high equity incentive for CEOs.

Callen, Fang, Xin \& Knowledge advantage and stock price crash risk: Evidence from the office size of engagement auditors: They Zhang (2014)

examine the effects of the office size of the local engagement auditor on future price crash. They document a negative association between the two suggesting that large audit offices are better able to detect and deter bad news hoarding activities through knowledge advantage than their smaller counterparts. The negative association is more pronounced for firms with better shareholder protection consistent with the interaction of audit incentives, induced by governance mechanisms, and engagement office ability in mitigating crash risk. 